\title{
Characteristics of Organic Macerals and Their Influence on Hydrocarbon Generation and Storage: A Case Study of Continental Shale of the Yanchang Formation from the Ordos Basin, China
}

\author{
Lei Xiao, ${ }^{1,2}$ Zhuo Li ${ }^{1,2}$, Yufei Hou, ${ }^{1,2}$ Liang Xu, ${ }^{1,2}$ Liwei Wang, ${ }^{1,2}$ and Youdong Yang ${ }^{1,2}$ \\ ${ }^{1}$ State Key Laboratory of Petroleum Resources and Prospecting, China University of Petroleum, Beijing 102249, China \\ ${ }^{2}$ Unconventional Petroleum Research Institute, China University of Petroleum, Beijing 102249, China \\ Correspondence should be addressed to Zhuo Li; lizhuopaper@163.com
}

Received 29 January 2021; Accepted 25 June 2021; Published 15 July 2021

Academic Editor: Julie Pearce

Copyright ( 2021 Lei Xiao et al. This is an open access article distributed under the Creative Commons Attribution License, which permits unrestricted use, distribution, and reproduction in any medium, provided the original work is properly cited.

\begin{abstract}
Organic macerals are the basic components of organic matter and play an important role in determining the hydrocarbon generation capacity of source rock. In this paper, organic geochemical analysis of shale in the Chang 7 member of the Yanchang Formation was carried out to evaluate the availability of source rock. The different organic macerals were effectively identified, and the differences in hydrocarbon generation and pore-forming capacities were discussed from two perspectives: microscopic pore development and macroscopic hydrocarbon generation through field emission scanning electron microscopy (FE-SEM) and energy-dispersive spectrum (EDS) analyses, methane isotherm adsorption, and on-site analysis of gas-bearing properties. The results show that the source rock of the Chang 7 member has a high abundance of organic matter and moderate thermal evolution and that the organic matter type is mainly type I. Based on the morphology of the organic matter and the element and pore development, four types of hydrogen-rich macerals, including sapropelite and exinite, and hydrogen-poor macerals, including vitrinite and inertinite, as well as the submacerals, algae, mineral asphalt matrix, sporophyte, resin, semifusinite, inertodetrinite, provitrinite, euvitrinite, and vitrodetrinite, can be identified through FE-SEM and EDS. A large number of honeycomb-shaped pores develop in sapropelite, and round-elliptical stomata develop in exinite, while vitrinite and inertinite do not develop organic matter pores. The hydrogen-rich maceral is the main component of organic macerals in the Chang 7 member of the Yanchang Formation. The weight percentage of carbon is low, so it has good hydrocarbon generation capacity, and the organic matter pores are developed and contribute $97 \%$ of the organic matter porosity, which is conducive to hydrocarbon generation and storage. The amount of hydrogen-poor maceral is low, and the weight percentage of carbon is low, and the organic matter pores are not developed, which is not conducive to hydrocarbon generation and storage.
\end{abstract}

\section{Introduction}

Organic maceral is a component of organic matter and has an important effect on hydrocarbon generation capacity [1, 2]. The method for identifying macerals in shale is derived from coal petrology, which involves complex sample preparation and uses transmitted light fluorescence to identify different macerals [3-5]. FE-SEM is an effective method to describe and analyze shale pore types and pore structure with simple sample preparation methods and high resolution.
Maceral is clearly visible under FE-SEM. Previous research used FE-SEM to effectively identify the organic maceral of the Shahezi Formation in the Songliao Basin, China, but did not detect the sapropelite and exinite, and the identification methods were not systematic [6]. The amount of research on continental shale is relatively low, and there is less research on the organic maceral of the Ordos Basin. Previous studies have shown that there is heterogeneity in the development of organic matter pores, but they have not studied its correlation with organic maceral $[7,8]$. At present, 
sapropelite and exinite are generally classified as hydrogenrich macerals, which is an important support for organic matter in the generation of oil. The higher the content of hydrogen-rich macerals, the higher the hydrocarbon generation capacity will be, while vitrinite and inertinite are classified as hydrogen-poor macerals with low hydrocarbon generation capacity [9]. There is a lack of in-depth research on the difference in hydrocarbon generation and poreforming capacities of different macerals.

The Ordos Basin is the second largest sedimentary basin in China, and the continental shale of the Chang 7 member of the Yanchang Formation is an important source rock in the region. In this paper, the research focused on Chang 7 shale samples, and FE-SEM combined with EDS methods was used to identify each organic maceral. The contribution of each maceral to the pore-forming capacity of organic matter and the relationship between macerals and hydrocarbon generation potential and gas content were studied. The relationship between organic maceral and hydrocarbon storage capacity was examined from both the microscopic and macroscopic perspectives. This research provides theoretical support for the in-depth understanding of the hydrocarbon generation capacity of organic matter and has a positive effect on the exploration and development of continental shale gas.

\section{Regional Geological Characteristics}

The Ordos Basin is located in the central part of mainland China, in the western part of the North China Platform, spanning three provinces and two regions (Shanxi, Gansu, Ningxia, and Inner Mongolia). It is bounded by the Yellow River fault to the north, the Weihe River north margin fault to the south, Liupan Mountain and Yinchuan Basin to the west, and the Lishi fault zone with the Lvliang uplift to the east. The basin has experienced a series of complex tectonic movements such as Lvliang, Caledonian, Indosinian, and Yanshan, forming the geological features of the wide and gentle east and narrow west, the well-developed peripheral faults, and the simple structure in the basin $[10,11]$. Based on the current structural morphology and basin evolution history, the basin can be divided into six tectonic units: the Yimeng uplift in the north, the Weibei uplift in the south, the western edge thrust belt in the west, the Jinxi folding belt in the east, and the Tianhuan depression and Yishan slope in the central region (Figure $1(\mathrm{a}))[12,13]$. The Triassic Yanchang Formation is one of the important oil-generating reservoirs in the basin. During the sedimentary period, the basin experienced a process of rapid development and then extinction, with the characteristics of the sedimentary evolution cycle. The continental sedimentary system of the riverlake-delta is widely developed. The Yanchang Formation can be divided into ten members from top to bottom. The upper part is composed of shale and thin siltstone, and the lower part is mainly composed of sand-shale interbeds (Figure 1(b)) [14]. In the Chang 7 member, the basin developed to its peak. The sedimentary facies were mainly deep lakes and semideep lakes, with developed organic-rich black shale and a small amount of siltstone and siltstone $[15,16]$.

\section{Samples and Methodology}

In this paper, a total of 410 shale samples from the Yanchang Formation were collected from shale gas wells of the Ordos Basin, China. Total organic content (TOC) analysis and rock pyrolysis were conducted on the 410 samples. TOC analysis was performed with a Leco CS230 carbon-sulfur analyzer. One gram of the sample was added to a crucible, and then the inorganic carbon was removed with dilute hydrochloric acid, and the sample was then rinsed with distilled water; the sample was then dried in an oven at $100^{\circ} \mathrm{C}$ for $12 \mathrm{~h}$ to perform TOC measurement. Rock-Eval analysis was carried out using an OGE-II rock pyrolyzer (RIPED, Beijing, China) under programmed heating processes. Then, the Tmax (the temperature at which the maximum number of hydrocarbons is generated) and other thermal parameters were obtained [17]. Vitrinite reflectance (Ro, \%) values were identified using an MPM-80-type microspectrophotometer at a temperature of $25^{\circ} \mathrm{C}$ and a relative humidity of $65 \%$. A total of 79 Ro data points were obtained. A total of 78 samples were used to quantify the organic maceral. Samples were crushed and sieved to a range size of $60 \sim 80 \mathrm{mesh}$, cemented with epoxy resin, and prepared into a $3 \mathrm{~cm} \times 3 \mathrm{~cm}$ particle light sheet. According to the characteristics and the color, shape, and intensity of fluorescence under the Leica DM4500P polarizing microscope, the organic macerals were identified and the contents were analyzed by statistical methods.

A Zeiss Merlin field emission scanning electron microscope was used to examine samples at a temperature of $24^{\circ} \mathrm{C}$ and a relative humidity of $35 \%$. Shale sections of $1 \mathrm{~cm}$ $\times 1 \mathrm{~cm}$ were $\mathrm{Ar}$ ion-milled to create an ultrasmooth surface and then coated with carbon. The working voltage was set to $2 \mathrm{kV}$, and the working distance was $3 \sim 4 \mathrm{~mm}$. The elemental composition of the mineral was determined using the EDAX ternary integrated system. Methane isotherm adsorption was measured using the FY-KT 1000 isotherm adsorption instrument at a temperature of $40^{\circ} \mathrm{C}$ and humidity of $2.12 \%$. Samples were prepared by crushing and sieving to a size of 80 mesh and weighing, and $100 \mathrm{~g}$ portions were weighed out for moisture equilibrium treatment. The moisture equilibrium was processed for at least four days for each sample. After these pretreatments, samples were put into the apparatus for the isotherm adsorption test [18]. Eight pressure points were measured, and the time for each pressure point to reach equilibrium was not less than 12 hours. Then, the ideal gas equation of state was used to calculate the adsorption capacity of each point, and finally, the isotherm adsorption curve was obtained through regression. The total gas content was measured by on-site analysis using the gasbearing experiment and the KD-III shale gas field analyzer developed by China University of Petroleum, Beijing.

\section{Results}

\subsection{Organic Geochemistry}

4.1.1. Om Richness. The abundance of organic matter is an important parameter for evaluating the quality of source 

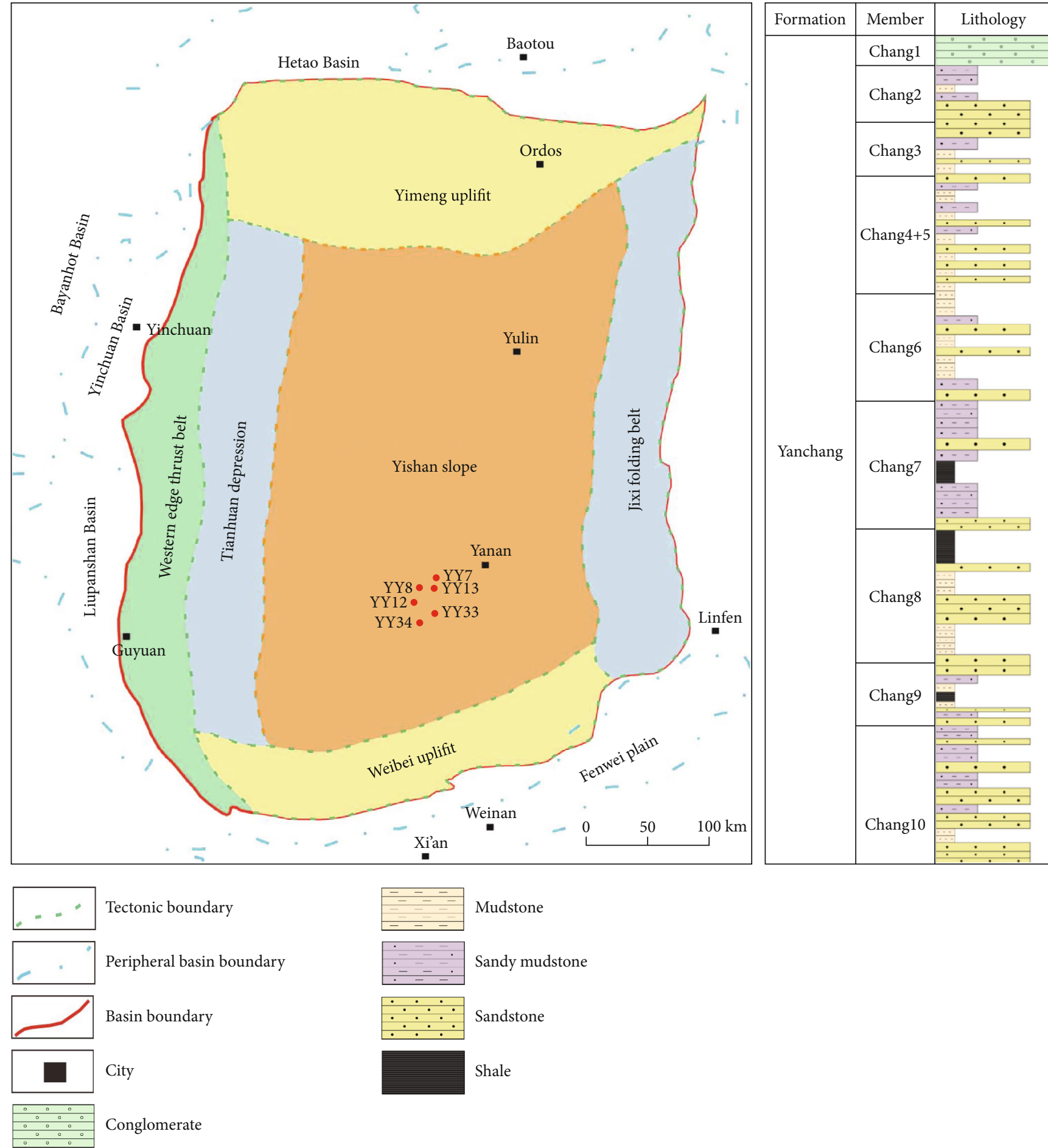

(a)

(b)

Figure 1: (a) The structural zones of the Ordos Basin. (b) The stratigraphic column of the Yanchang Formation in the Ordos Basin.

rocks, usually using TOC, chloroform pitch "A," and hydrocarbon generation potential $\left(S_{1}+S_{2}\right)$. A total of 410 samples of the Chang 7 member in the Yanchang Formation were examined by TOC analysis and pyrolysis analysis. Statistics indicated that the TOC of the Chang 7 member shale was $0.2 \% \sim 13 \%$, with an average of $4.6 \%$ (Figure $2(\mathrm{a})$ ); the content of chloroform pitch "A" was $0.73 \% \sim 1.75 \%$, with an average of $1.26 \%$; the amount of hydrocarbon generation potential was $0.6 \sim 30 \mathrm{mg} / \mathrm{g}$, with an average of $12.9 \mathrm{mg} / \mathrm{g}$, which had a good positive correlation with TOC, indicating that the shale of the Chang 7 member has good hydrocarbon generation potential (Figure 2(b)). 


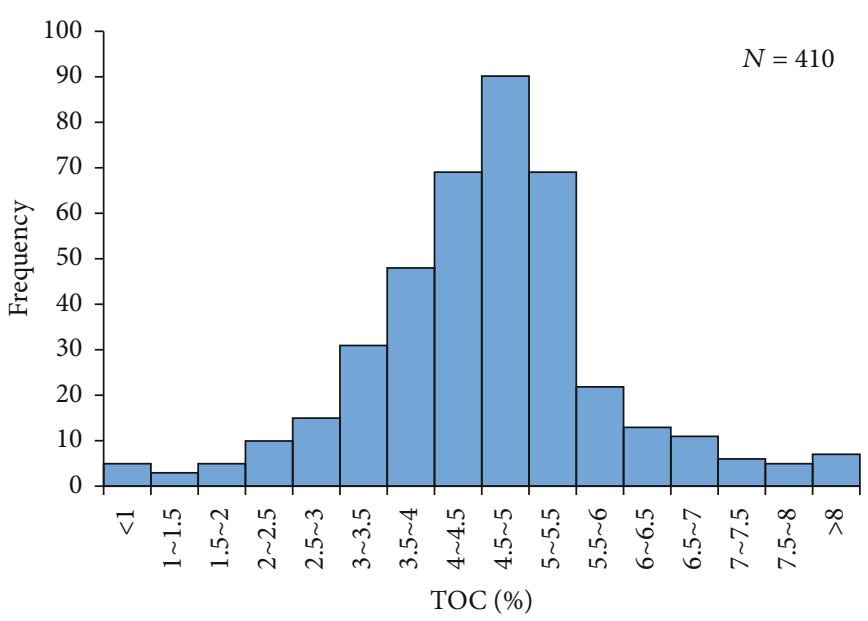

(a)

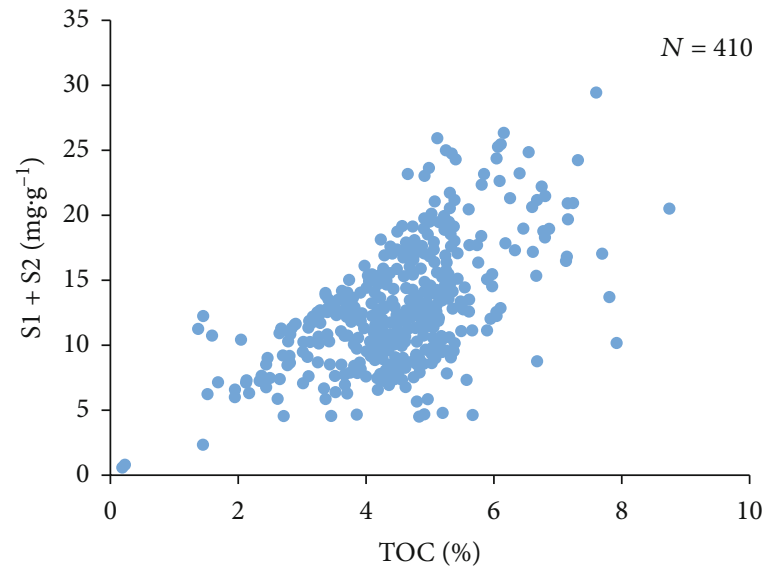

(b)

FIgURE 2: (a) The TOC frequency distribution. (b) The relationship between TOC and $S_{1}+S_{2}$.

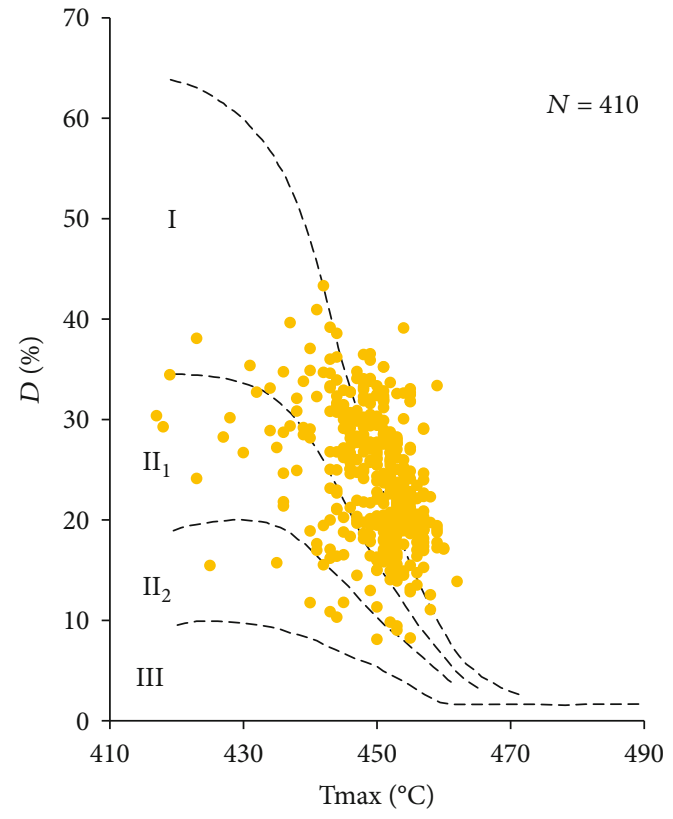

(a)

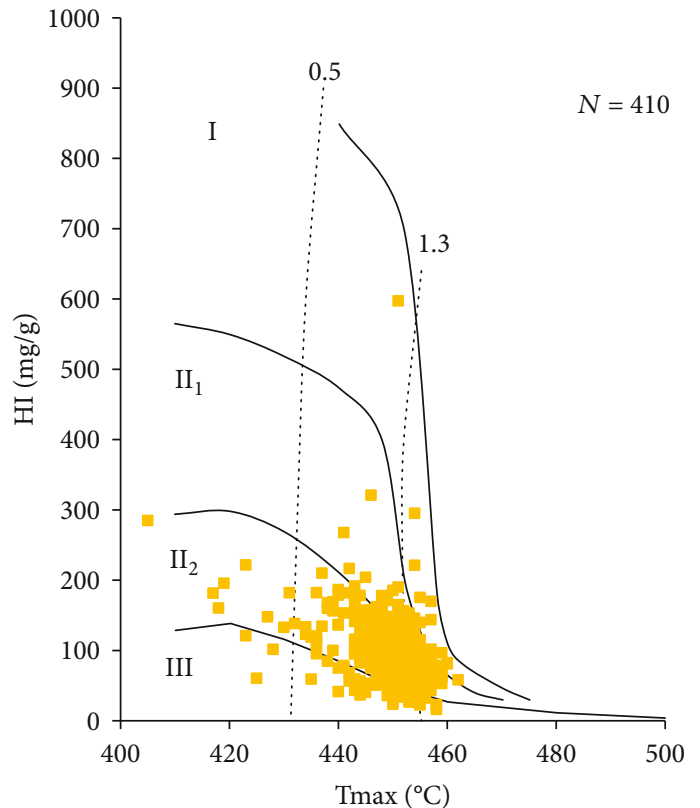

(b)

Figure 3: (a) Tmax- $D$ crossplot. (b) Tmax-HI crossplot.

4.1.2. Om Type. The ability of source rock to generate hydrocarbon is not only related to the abundance of organic matter but also determined by the type of organic matter. Rock pyrolysis parameters can effectively classify the organic matter types mainly based on the crossplot of the pyrolysis parameters: maximum pyrolysis peak temperature (Tmax) and hydrogen index $(\mathrm{HI})$ or degradation rate $(D)$. Among the samples analyzed in this pyrolysis, $D$ was $8 \% \sim 43 \%$, with an average of $24 \%$. According to the Tmax-D crossplot (Figure 3(a)), the organic matter of Chang 7 shale was mainly type I with a small amount of type $\mathrm{II}_{1}$; $\mathrm{HI}$ was $16 \sim 597 \mathrm{mg} / \mathrm{g}$, with an average of $103 \mathrm{mg} / \mathrm{g}$. According to the Tmax-HI crossplot (Figure 3(b)), the organic matter type was mainly type II. Most of the samples generate hydrocarbon that migrates out of source rock, which leads to low HI, mostly less than $300 \mathrm{mg} / \mathrm{g}$, and further affects the identification of organic matter types using the Tmax-HI crossplot. In summary, the organic matter type of the Chang 7 member in the Yanchang Formation is mainly type I, with a small amount of type $\mathrm{II}_{1}$.

4.1.3. Thermal Maturity. The abundance and type of organic matter are the necessary basis components for source rock hydrocarbon generation, but maturity is the necessary condition for determining whether a large amount of hydrocarbon can be generated. Only when the oil generation window or the gas generation window is reached can a large amount of hydrocarbon be generated under the action of heat. At 


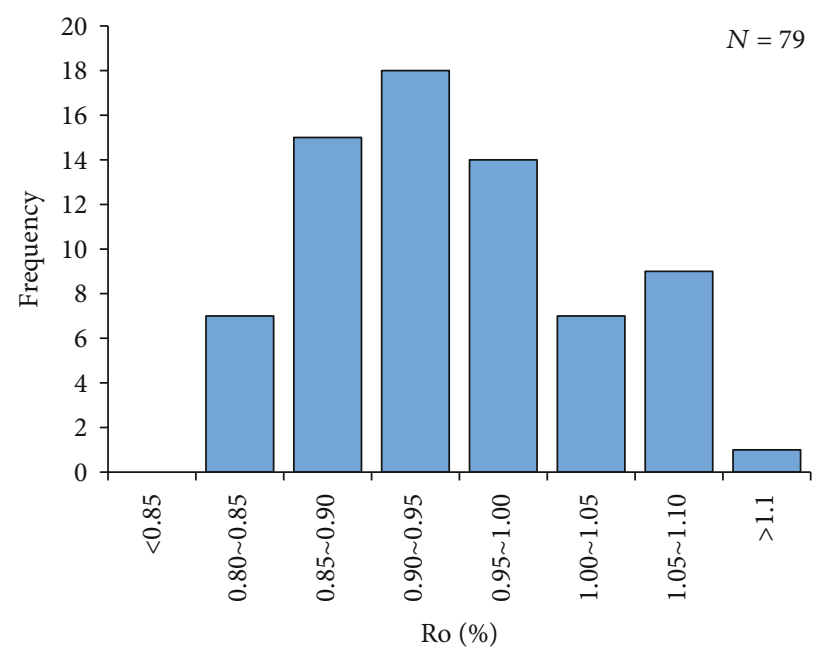

(a)

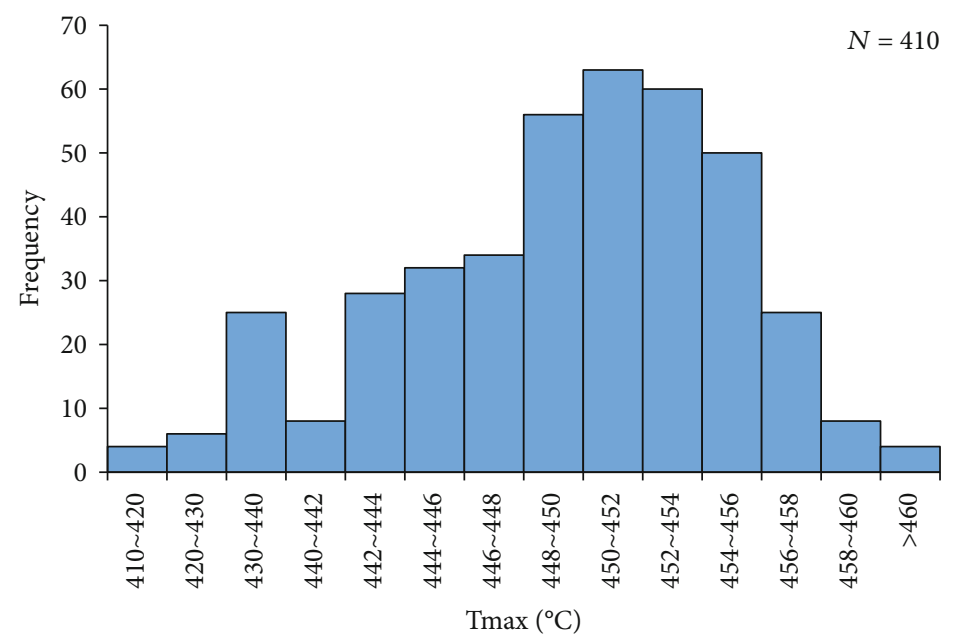

(b)

FIgure 4: (a) The Ro frequency distribution. (b) The Tmax frequency distribution of source rocks in the Chang 7 member.

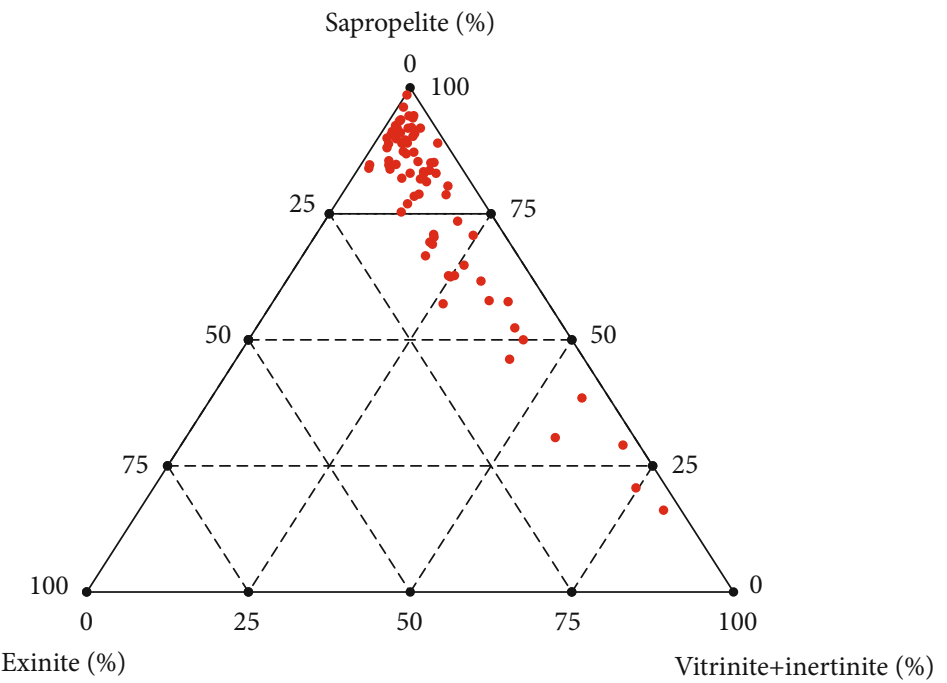

FIGURE 5: The kerogen maceral triangulation in source rocks of the Chang 7 member in the Ordos Basin. 

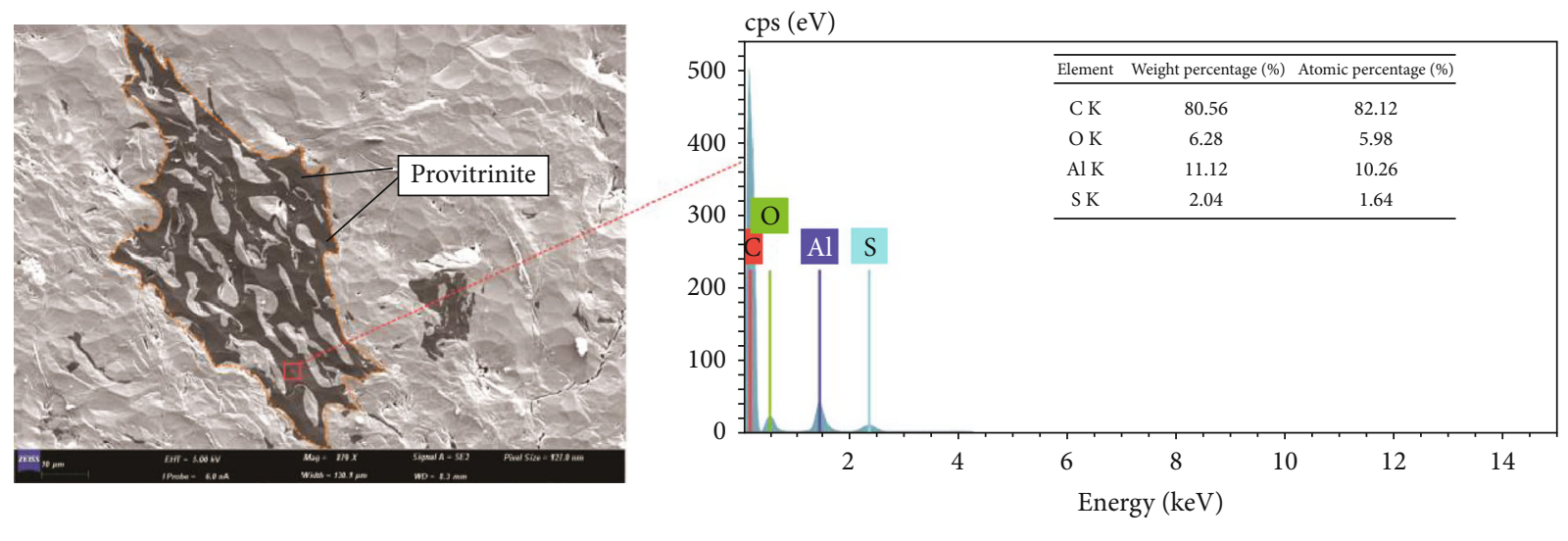

(a)
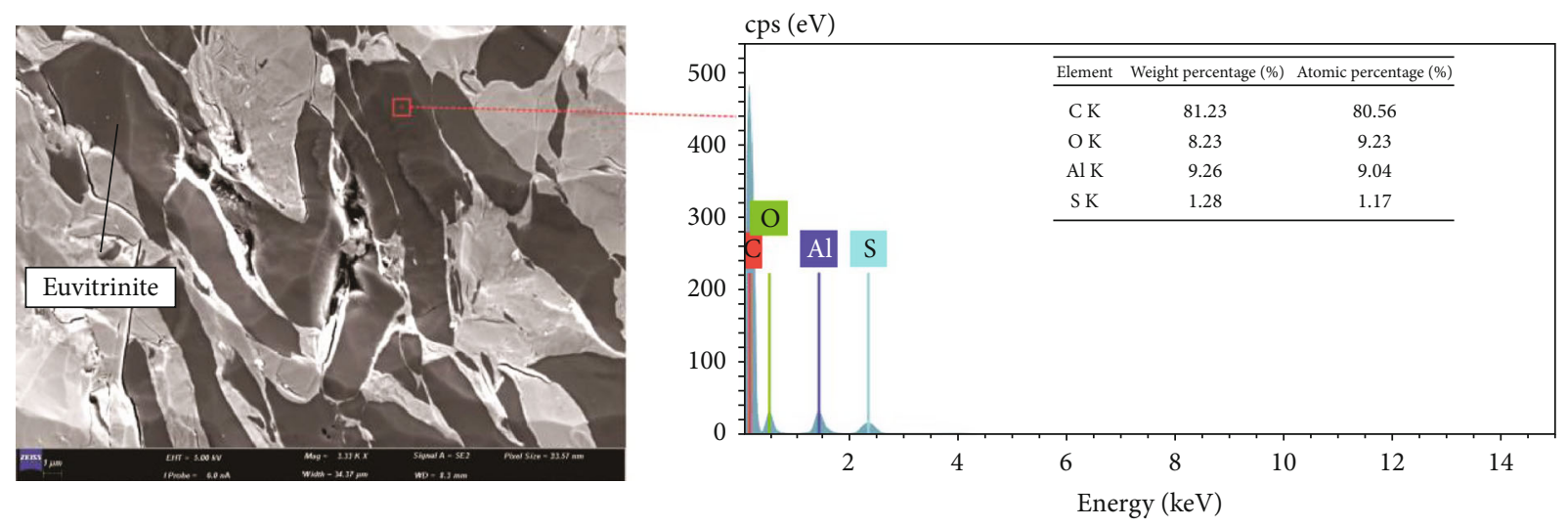

— Point

(b)
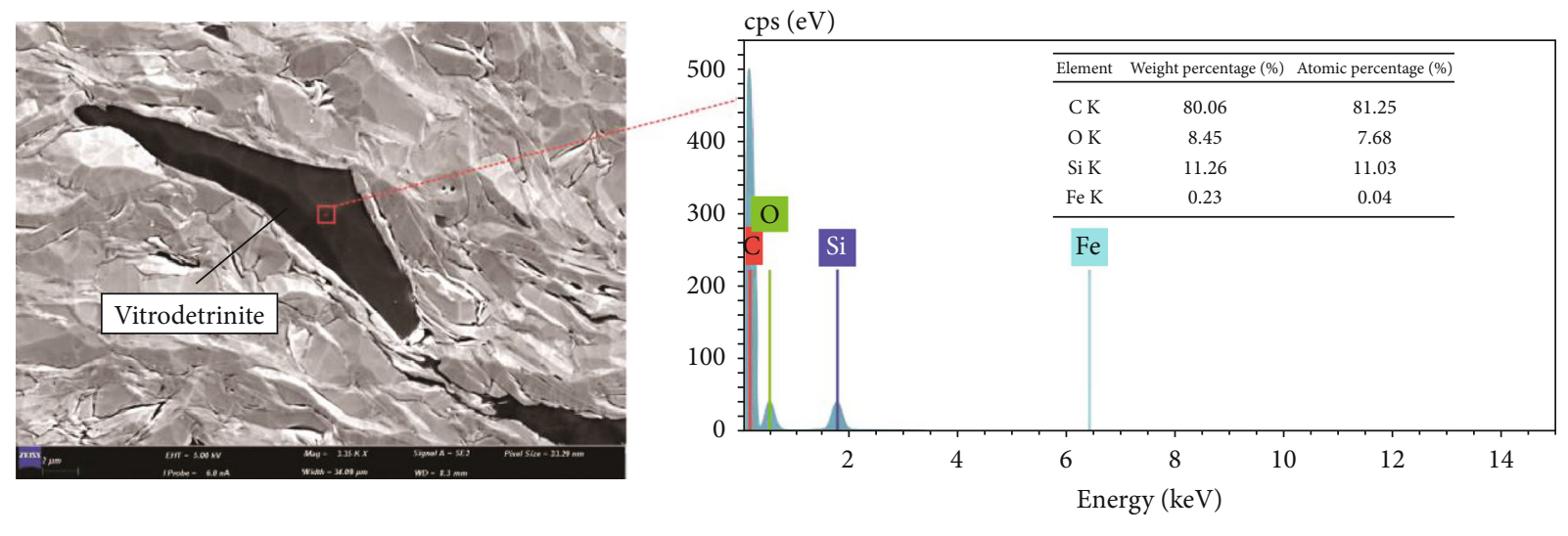

— Point

(c)

FIGURE 6: Characteristics of vitrinite under FE-SEM. (a) YY33, $1607.30 \mathrm{~m}$, provitrinite. (b) YY33, $1622.80 \mathrm{~m}$, euvitrinite. (c) YY34, 1396.37 m, vitrodetrinite. The EDS of the corresponding points are shown on the right.

present, the commonly used identification indexes are vitrinite reflectance (Ro) and maximum pyrolysis peak temperature (Tmax). The analysis showed that the Ro was $0.82 \% \sim 1.09 \%$, with an average of $0.92 \%$ (Figure $4(\mathrm{a})$ ); Tmax was $349^{\circ} \mathrm{C} \sim 462^{\circ} \mathrm{C}$, with an average of $448^{\circ} \mathrm{C}$ (Figure $4(\mathrm{~b})$ ).
The Chang 7 shale is in the mature stage and mainly generates oil by kerogen pyrolysis.

4.2. Organic Macerals. The kerogen organic macerals play an important role in classifying organic matter types and 

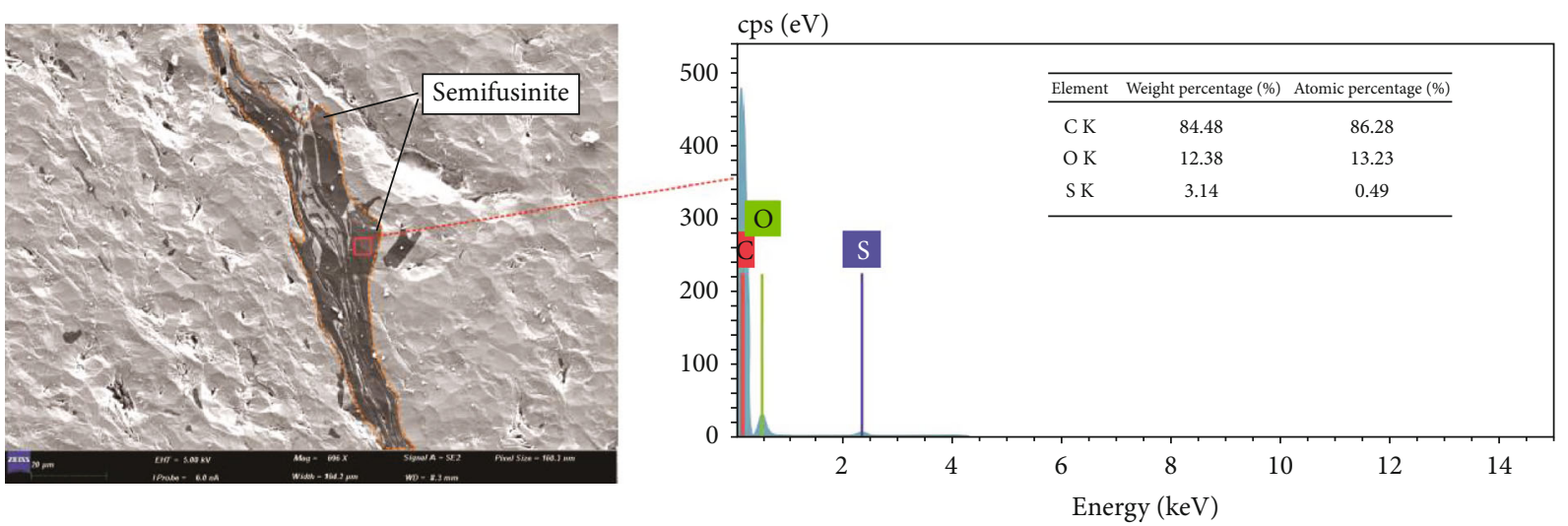

— Point

(a)
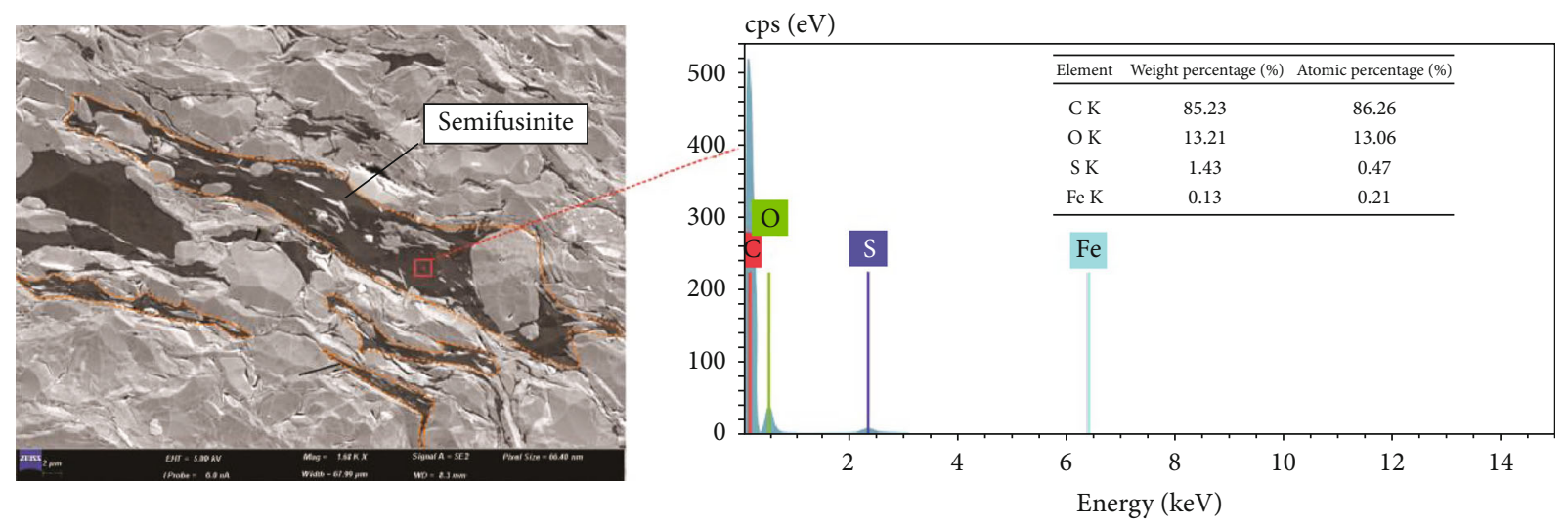

— Point

(b)
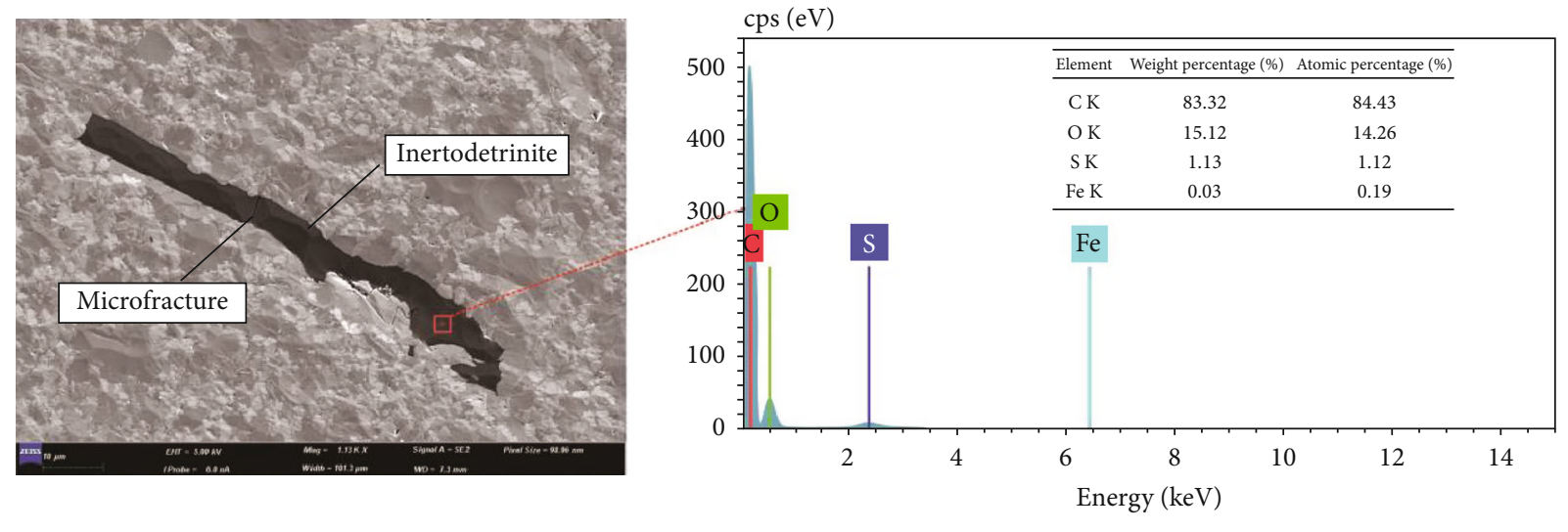

— Point

(c)

Figure 7: Characteristics of inertinite under FE-SEM. (a) YY33, $1622.8 \mathrm{~m}$, semifusinite. (b) YY33, $1622.8 \mathrm{~m}$, semifusinite. (c) YY33, $1622.8 \mathrm{~m}$, inertodetrinite and microfracture. The EDS of the corresponding points are shown on the right.

revealing the hydrocarbon generation potential of source rock. There are various names and classification methods for organic maceral $[19,20]$. This article refers to the Chinese standard SY/T 6414 to classify maceral. Through identification and quantitative analysis of macerals of 78 shale samples from the Chang 7 member, it was found that the organic matter was composed of sapropelite, exinite, vitrinite, and inertinite. The relative percentage content of sapropelite was $16.2 \% \sim 98.6 \%$, with an average of $77.9 \%$, indicating that it mainly accepted the input of organic matter such as planktonic algae and lower microorganisms; the relative percentage content of exinite was $1.2 \% \sim 16 \%$, with an average of 

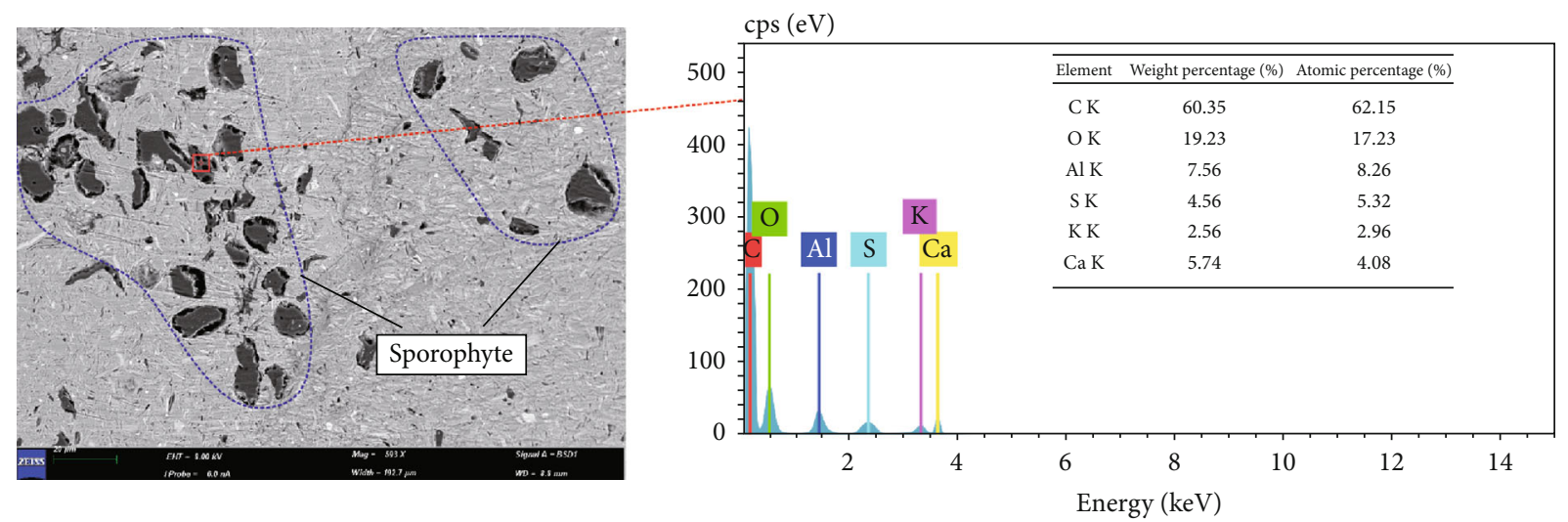

— Point

(a)
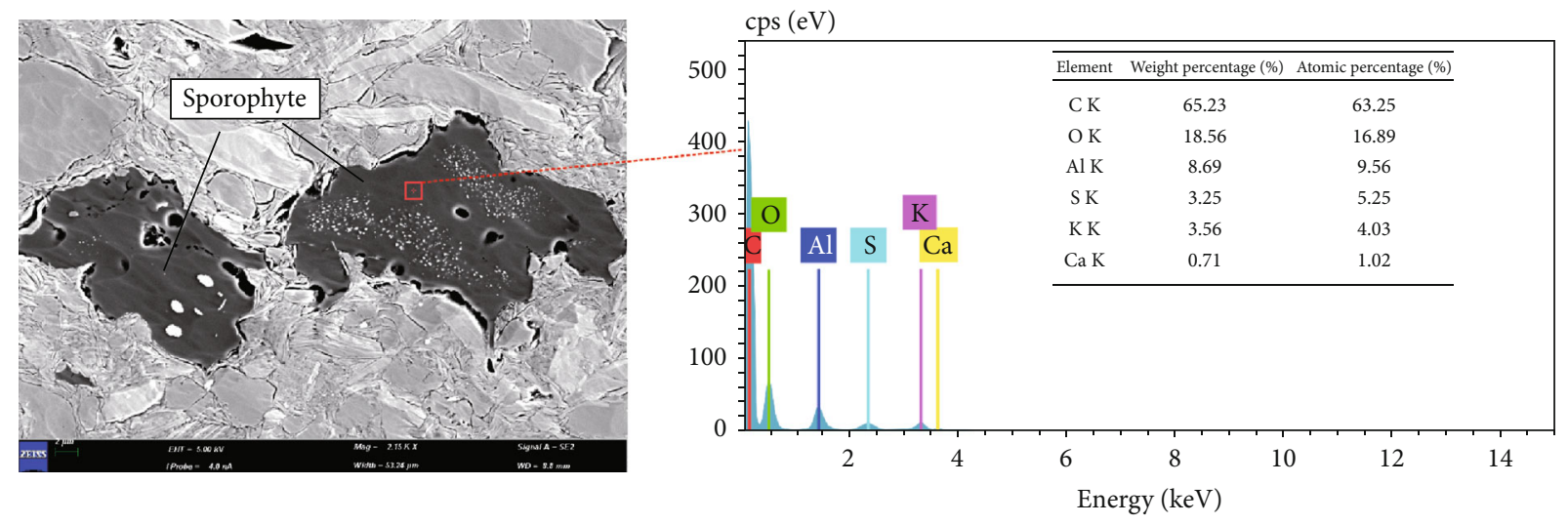

— Point

(b)
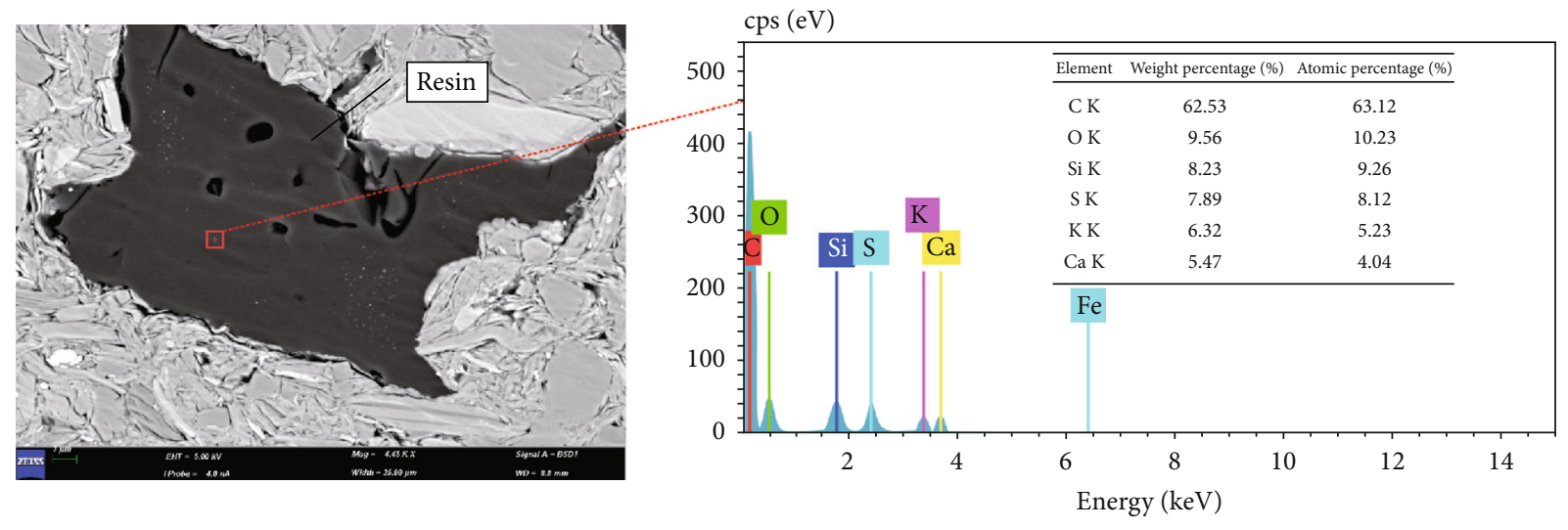

- Point

(c)

FIGURE 8: Characteristics of exinite under FE-SEM. (a) YY33, $1622.8 \mathrm{~m}$, sporophyte. (b) YY33, $1622.8 \mathrm{~m}$, sporophyte. (c) YY33, $1622.8 \mathrm{~m}$, resin. The EDS of the corresponding points are shown on the right.

$7.2 \%$; the relative percentage of vitrinite was $0.2 \% \sim 81.1 \%$, with an average of $13.8 \%$; the relative percentage of inertinite was $0.4 \% \sim 8.9 \%$, with an average of $1.0 \%$. The kerogen maceral triangulation showed that sapropelite is the main component of the Chang 7 shale kerogen, and the organic matter was mainly type I (Figure 5).
4.2.1. Vitrinite. Vitrinite is the product of humification and gelation of the wood fiber tissue of higher plants [21]. Vitrinite has a darker color, smooth surface, and uniform texture, is enriched in bands or clumps, and generally does not develop pores under FE-SEM. Due to the difference in the degree of gelation, the cell structure of the original plant is 

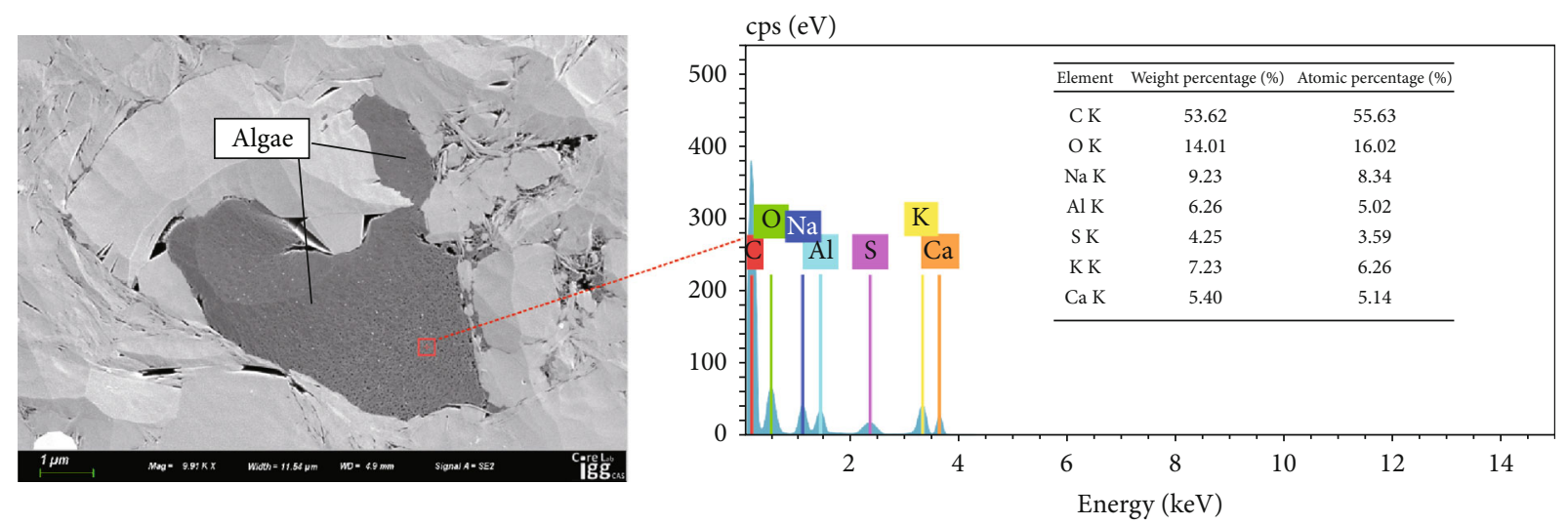

— Point

(a)
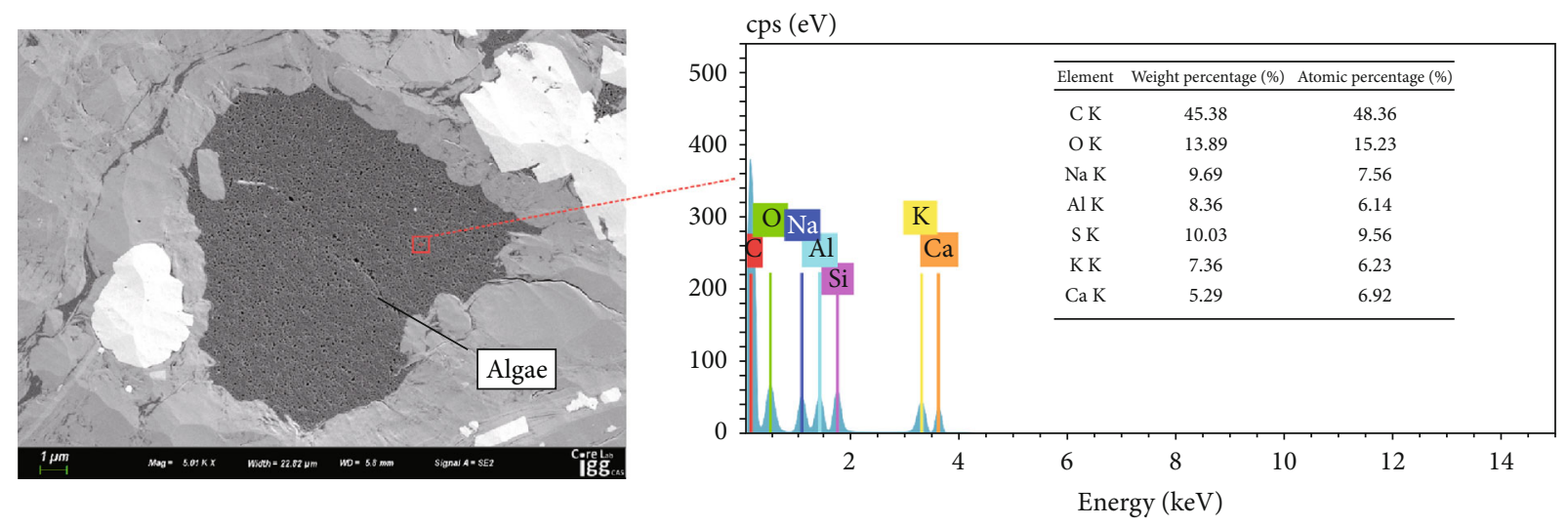

Point

(b)
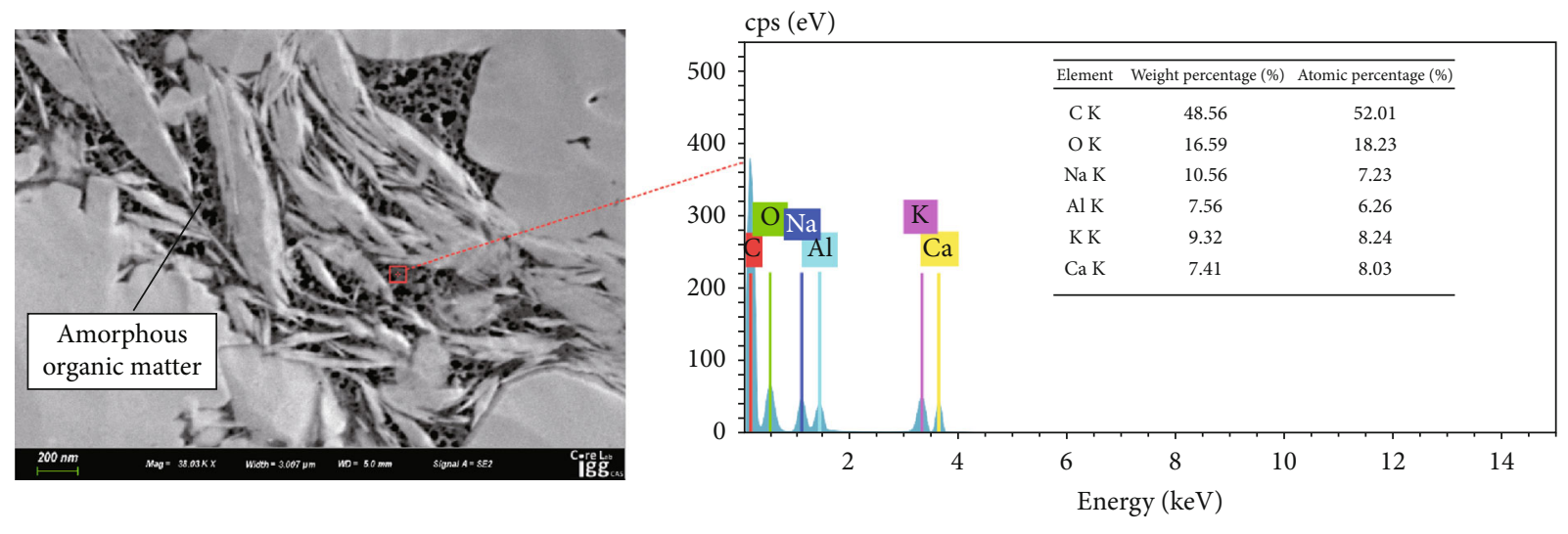

— Point

(c)

Figure 9: Characteristics of sapropelite under FE-SEM. (a) YY33, $1622.8 \mathrm{~m}$, algae. (b). YY33, $1622.8 \mathrm{~m}$, algae. (c) YY7, $1153.35 \mathrm{~m}$, amorphous organic matter. The EDS of the corresponding points are shown on the right.

preserved differently. Based on this, vitrinite can be subdivided into provitrinite, euvitrinite, and vitrodetrinite. Provitrinite can be clearly observed under the electron microscope in the cell wall and cell cavity structure of the original plant. The cell wall often deforms and bends under compaction, and the cell cavity becomes different in shape due to pressure, which is oval or arc-shaped. The interior is often filled with inorganic minerals (Figure 6(a)). The cell structure of the primitive plants of euvitrinite is not visible under strong gelation. The results showed that the euvitrinite of the Chang 7 member is mainly matrix vitrinites, which have smooth surfaces, dense texture, rich shapes, and bands 
TABLE 1: Main identification features of organic macerals under FE-SEM for Chang 7 shale in the Ordos Basin.

\begin{tabular}{|c|c|c|c|}
\hline Maceral & Submaceral & Characteristics under FE-SEM & EDS \\
\hline \multirow{3}{*}{ Vitrinite } & Provitrinite & $\begin{array}{l}\text { Visible cell structure, distorted cell wall, cell cavity filled with inorganic minerals, undeveloped } \\
\text { pore }\end{array}$ & \multirow{3}{*}{$\begin{array}{c}\text { C: } \\
80 \% \sim 90 \% \\
\text { O: }<10 \%\end{array}$} \\
\hline & Euvitrinite & Invisible cell structure, banded and cloddy, undeveloped pore & \\
\hline & Vitrodetrinite & Obvious protrusions, fragmentary with sharp edges, undeveloped pore & \\
\hline \multirow{2}{*}{ Inertinite } & Semifusinite & $\begin{array}{l}\text { Swelling cell wall, combined with the surrounding matrix tightly, cell cavity filled with minerals, } \\
\text { ribbon-shaped, underdeveloped pore }\end{array}$ & \multirow{2}{*}{$\begin{array}{c}\text { C: } \\
80 \% \sim 90 \% \\
\text { O: }>10 \%\end{array}$} \\
\hline & Inertodetrinite & $\begin{array}{l}\text { Invisible cell structure, fragmentary with angular, arc-shaped, or other morphologies, transverse } \\
\text { microcracks developed }\end{array}$ & \\
\hline \multirow[t]{2}{*}{ Exinite } & Sporophyte & $\begin{array}{c}\text { Ellipsoidal, worm-like, and irregular shapes, cluster distribution round-elliptical large pores } \\
\text { developed }\end{array}$ & \multirow{2}{*}{$\begin{array}{c}\text { C: } \\
60 \% \sim 70 \% \\
\text { O: }>10 \%\end{array}$} \\
\hline & Resin & Elliptical or irregular without cell structure, flat surface, circular-elliptical large pores developed & \\
\hline \multirow{2}{*}{ Sapropelite } & Algae & $\begin{array}{c}\text { Various shapes, cluster distribution, uneven surface, jagged edges, honeycomb-shaped pores } \\
\text { developed }\end{array}$ & \multirow{2}{*}{$\begin{array}{c}\text { C: } \\
40 \% \sim 60 \% \\
\text { O: }>10 \%\end{array}$} \\
\hline & $\begin{array}{l}\text { Mineral asphalt } \\
\text { matrix }\end{array}$ & $\begin{array}{c}\text { No fixed shape, unclear outline, mixed with inorganic minerals, large honeycomb pores } \\
\text { developed }\end{array}$ & \\
\hline
\end{tabular}

and clumps (Figure 6(b)). Vitrodetrinite is the detrital particles of vitrinite, mainly derived from peat-decomposed plants. The cell structure of the plant is not visible under FE-SEM, but the protrusions are obvious, often in the shape of bones and sharp edges (Figure 6(c)). EDS showed that the weight percentage of carbon in vitrinite was generally $80 \sim 90 \%$, and the weight percentage of oxygen was generally less than $10 \%$. Vitrinite is formed in a reducing environment and therefore has a low oxygen weight percentage [22].

4.2.2. Inertinite. Inertinite is formed by the carbonization of higher plants [23]. It is gray-black under FE-SEM, usually grid-like, ribbon-like, clump-like, and angular. The submacerals observed in samples are mainly semifusinite and inertodetrinite. Semifusinite is a component between fusinite and provitrinite. The cell wall swells strongly, and it is combined tightly with the surrounding matrix. The cell cavity is compressed and becomes smaller, filled with minerals. Semifusinite is ribbon-shaped, with underdeveloped pores (Figures $7(\mathrm{a})$ and $7(\mathrm{~b})$ ). Inertodetrinite is the fragments of fusinite, semifusinite, and sclerotinite. The cell structure of plants is not visible. It is gray-black, with angular, arc-shaped, and other morphologies, and it can develop transverse microcracks (Figure $7(\mathrm{c})$ ). It is difficult to distinguish between vitrinite and inertinite under FE-SEM.

Inertinite and vitrinite have similar shapes and structures, which are not easy to distinguish under FE-SEM, but the two can be effectively identified with the help of EDS. EDS showed that the weight percentage of carbon in inertinite was generally $80 \% \sim 90 \%$, which was similar to vitrinite, but the weight percentage of oxygen was generally greater than $10 \%$, which was significantly higher than vitrinite. This was mainly because the inertinite was formed in an oxidation environment, and the vitrinite was formed in a reducing environment, so the weight percentage of oxygen in inertinite was higher than that in vitrinite [22]. In addition, the inertinite had a higher protrusion, which is also an effective way to distinguish it from vitrinite.
4.2.3. Exinite. Exinite is derived from stable organs or metabolites in higher plants, such as resin and essential oil. It has good chemical stability and is not damaged by biochemical processes, so it is a good hydrocarbon generation material [21]. It had a high brightness under FE-SEM. Two submacerals, sporophyte and resin, were mainly observed in samples. Sporophyte is derived from the reproductive organs of plants and can be divided into macrospores $(>0.1 \mathrm{~mm})$ and microspores $(<0.1 \mathrm{~mm})$ according to their morphological size. Most of the microspores observed under FE-SEM have ellipsoidal, worm-like, and irregular shapes, with lowmedium protrusions, often distributed in groups, with round-elliptical large pores (Figures $8(\mathrm{a})$ and $8(\mathrm{~b})$ ). The resin is mainly formed by plant waxes, resins, and lipids and is generally regarded as a good hydrocarbon generation material. The surface was flat, the inside is uniform, and the shape was elliptical or irregular without cell structure, and there were circular-elliptical large pores (Figure 8(c)).

Previous studies have shown that the combination of organic matter and inorganic minerals is more likely to lead to the formation of organic matter pores [24]. Compared with other inorganic minerals, clay minerals are more likely to catalyze the formation of gaseous hydrocarbons [25]. In the process of hydrocarbon expulsion and pore generation, affected by the catalysis of clay minerals, the EDS of the organic matter showed inorganic mineral elements such as $\mathrm{Al}, \mathrm{K}, \mathrm{Mg}$, and Si. The weight percentage of carbon was found to be generally 60 to $70 \%$, and the weight percentage of oxygen generally exceeded $10 \%$. The influencing factors that control the development of organic matter pores are complicated. The hydrocarbon generated and organic acids may also be involved. This area requires needs further study to elucidate the mechanism.

4.2.4. Sapropelite. Sapropelite is the product of saprofication of lower aquatic organisms, such as algae [21]. Similar to exinite, it is a hydrogen-rich and oxygen-poor maceral in the source rock, which tends to generate oil. It is an excellent 

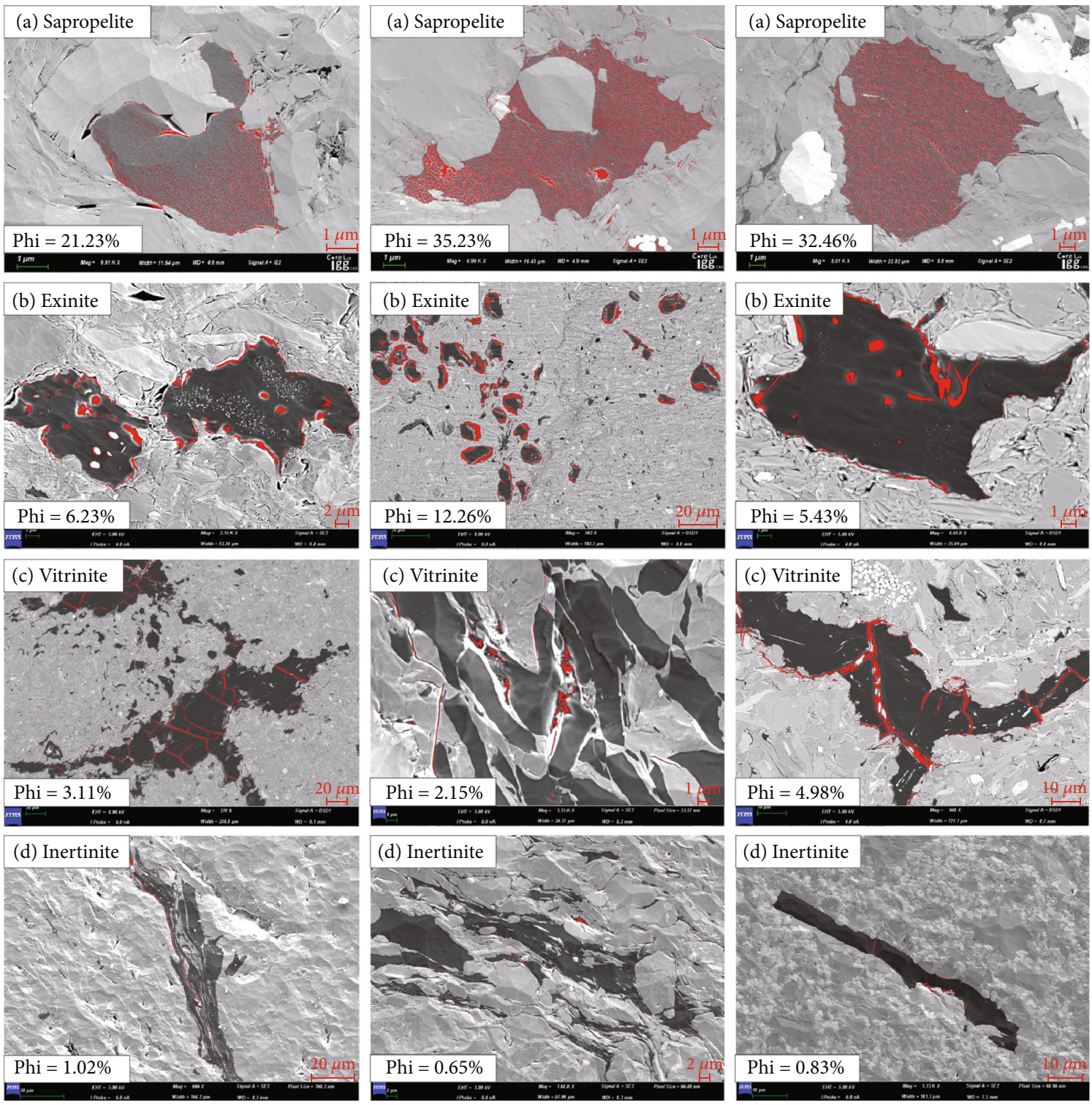

Figure 10: Schematic diagram of the Phi of each maceral extracted using the IPP software.

hydrocarbon generation material and the main component of the Chang 7 kerogen organic maceral. The color was lighter under FE-SEM. Two submacerals, algae and amorphous organic matter, were mainly observed in samples. Algae are the remains of single-celled or multicelled lower aquatic organisms and an important part of the hydrocarbon generation maceral. The algae had various shapes, with the characteristics of cluster distribution, uneven surface, and honeycomb-shaped pores, and the edges were often jagged under FE-SEM (Figures 9(a) and 9(b)).

Amorphous sapropelite mainly appears in the form of a mineral asphalt matrix, which is a composite of organic matter and inorganic minerals. The results showed that the mineral asphalt matrix of the Chang 7 member accounted for the absolute proportion of organic matter, with an average of more than $50 \%$, and plays an important role in hydrocarbon generation and the evaluation of source rock. The mineral asphalt matrix had no fixed shape, an unclear outline, was
TABLE 2: The contribution of each maceral to the organic matter pores of the Chang 7 member.

\begin{tabular}{lcccc}
\hline $\begin{array}{l}\text { Organic } \\
\text { maceral }\end{array}$ & $\begin{array}{c}\text { Weight } \\
\text { percentage } \\
(\%)\end{array}$ & $\begin{array}{c}\text { Average } \\
\text { Phi (\%) }\end{array}$ & Contribution & $\begin{array}{c}\text { Percentage } \\
\text { contribution } \\
(\%)\end{array}$ \\
\hline Sapropelite & 77.94 & 25.8 & 0.20109 & 94.96 \\
Exinite & 7.23 & 6.2 & 0.00448 & 2.12 \\
Vitrinite & 13.77 & 4.4 & 0.00606 & 2.86 \\
Inertinite & 1.06 & 1.1 & 0.00012 & 0.06 \\
\hline
\end{tabular}

mixed with inorganic minerals, and developed a large number of honeycomb pores (Figure 9(c)). The sapropelite was affected by the catalysis of clay minerals during the hydrocarbon generation process. The EDS showed inorganic mineral elements such as $\mathrm{K}, \mathrm{Na}, \mathrm{Mg}, \mathrm{Al}$, and $\mathrm{Si}$, and the weight percentage of carbon was low, generally $40 \sim 60 \%$, and the weight 


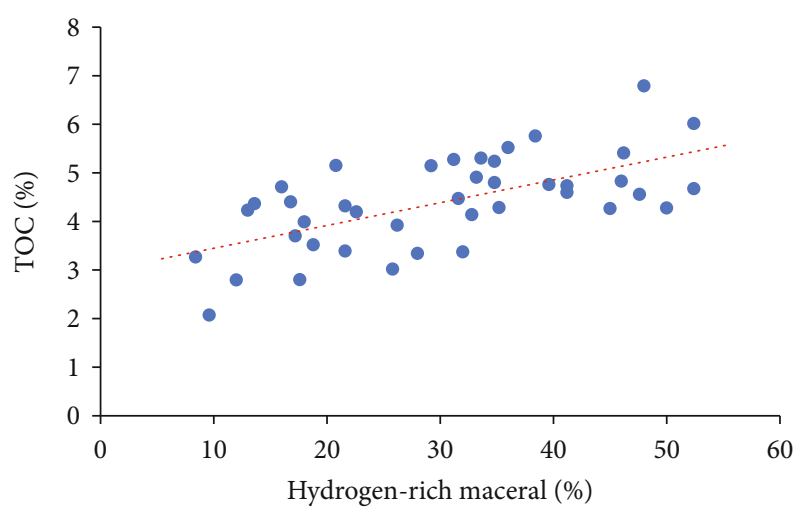

(a)

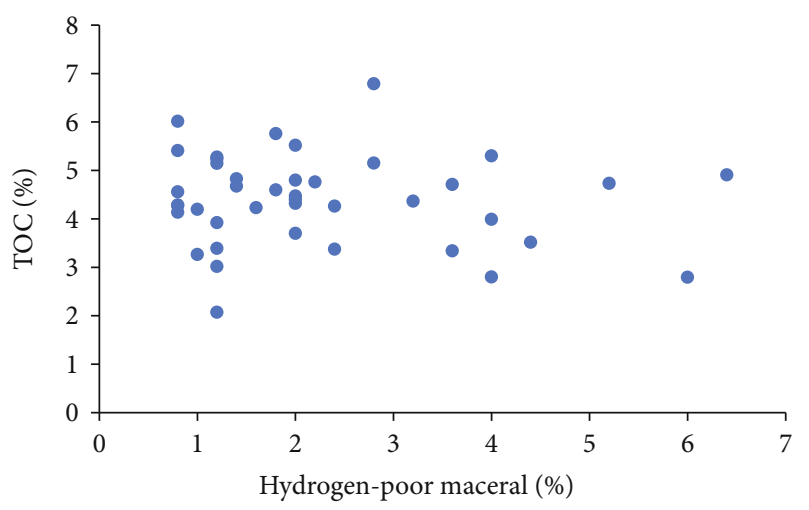

(c)

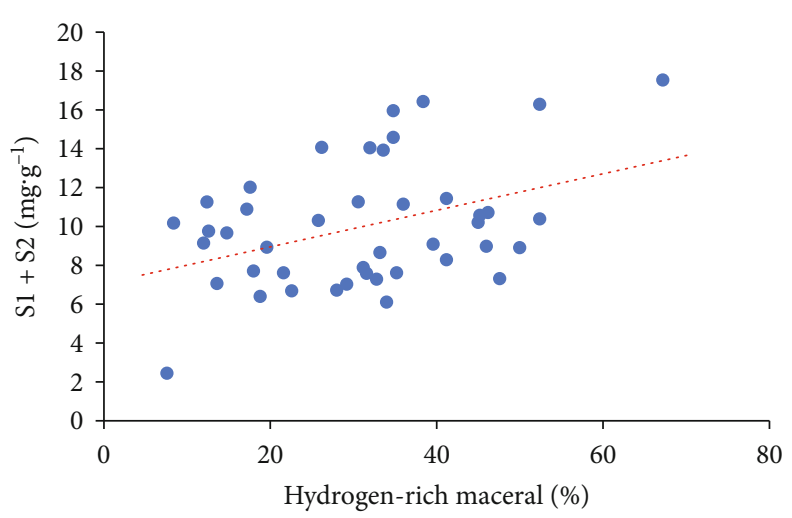

(b)

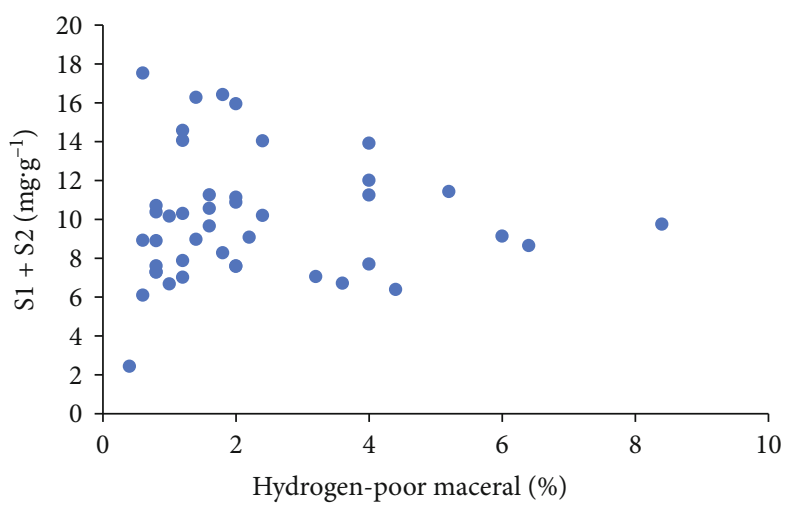

(d)

FIgURE 11: Relationships between macerals and TOC and $S_{1}+S_{2}$.

percentage of oxygen generally exceeded $10 \%$. The higher the weight percentage of carbon, the worse the hydrocarbon generation potential. Sapropelite had the best hydrocarbon generation potential, followed by exinite, vitrinite had a poor hydrocarbon generation potential, and inertinite had the worst generation potential.

4.2.5. Synthetic Discrimination of Organic Macerals. Based on FE-SEM and EDS, the organic macerals can effectively be identified by their morphology and elemental composition. Sapropelite and exinite had higher brightnesses, and the organic matter pores were developed. Sapropelite developed honeycomb-shaped pores, and exinite developed roundelliptical large pores. EDS showed that the oxygen of the two is greater than $10 \%$. The carbon of sapropelite was $40 \% \sim 60 \%$, while that of exinite was $60 \% \sim 70 \%$. Vitrinite and inertinite were dark with undeveloped organic matter pores under FE-SEM. EDS showed that the carbon of the above was $80 \% \sim 90 \%$. The oxygen of vitrinite was less than $10 \%$, while that of inertinite was greater than $10 \%$. The higher protrusion of inertinite was also an effective auxiliary method to distinguish it from vitrinite. The identification method of each submaceral is shown in Table 1.

\section{Discussion}

5.1. Control of Organic Matter Porosity by Macerals. It is assumed that the organic matter pores in the shale are evenly distributed, and the plane porosity of the entire space (Phi) on any organic matter section is equal. Therefore, the sample can be used to deduce the organic matter porosity through several scanning electron microscope pictures. The pore parameters were extracted using the Image-Pro Plus (IPP) software. First, the target area was selected; then, an appropriate gray value was set to divide the pore and matrix; and finally, the required parameters were selected. This study used Phi as the analysis parameter. Prior studies have done a lot of research on the methods to calculate organic matter porosity $[26,27]$; the calculation formula is as follows:

$$
\varphi_{\mathrm{org}}=\varphi_{\mathrm{s}} \times \frac{\omega_{\mathrm{TOC}}}{100} \times \frac{\rho_{\mathrm{s}}}{\rho_{\mathrm{org}}} \times 100 \%,
$$

where $\varphi_{\text {org }}, \varphi_{\mathrm{s}}$, and $\omega_{\text {TOC }}$ are the organic matter porosity, plane porosity of the entire space, and the weight percentage of organic matter, respectively; $\rho_{\mathrm{s}}$ represents the shale density, which is $2.6 \mathrm{~g} / \mathrm{cm}^{3}$; and $\rho_{\text {org }}$ represents the density of organic matter, which is $1.2 \mathrm{~g} / \mathrm{cm}^{3}$.

Using the shale sample of $1622.8 \mathrm{~m}$ of YY33 as an example, the results of extracting the Phi of each maceral under FE-SEM through the IPP software are shown in Figure 10. The Phi of sapropelite was $20 \% \sim 40 \%$; the Phi of exinite was $5 \% \sim 10 \%$; the Phi of vitrinite was $2 \% \sim 5 \%$; the Phi of inertinite was $<2 \%$. According to the formula, the organic porosity of the sample was $0.97 \%$. 

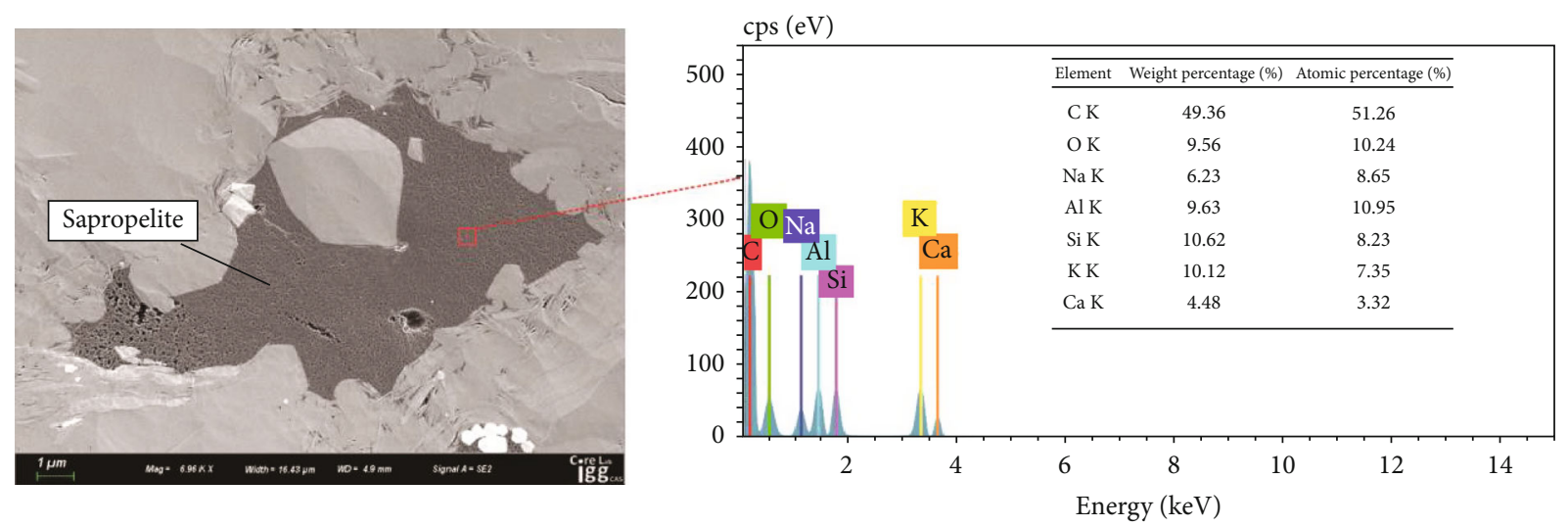

— Point

(a)
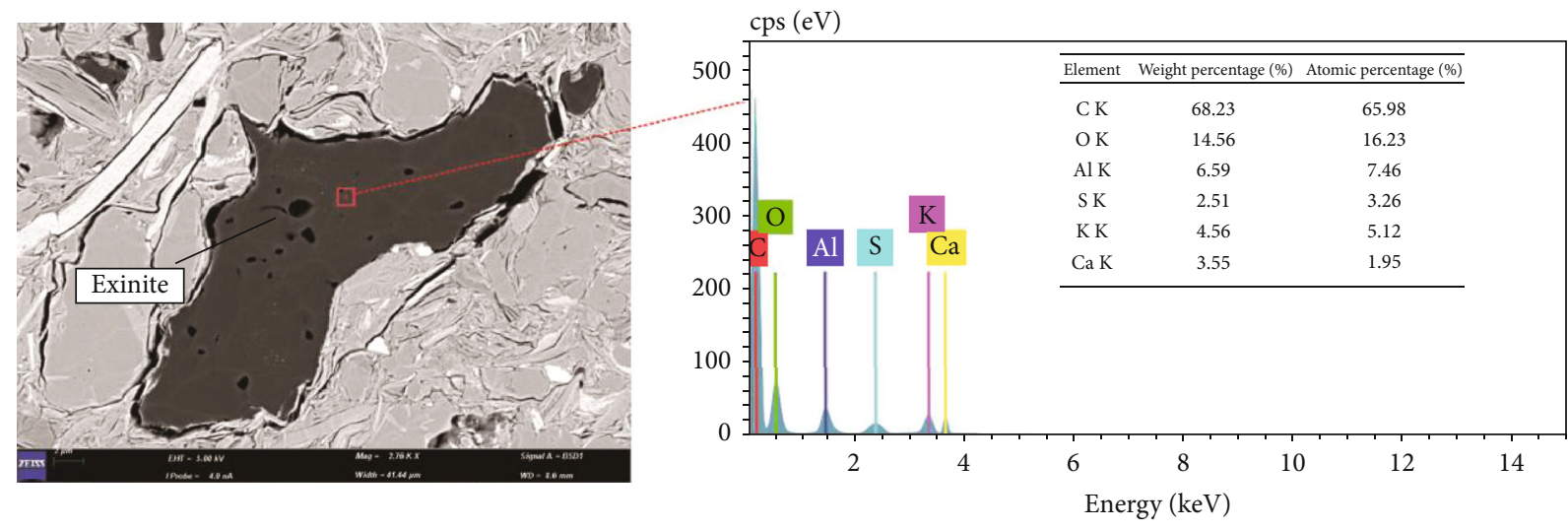

— Point

(b)
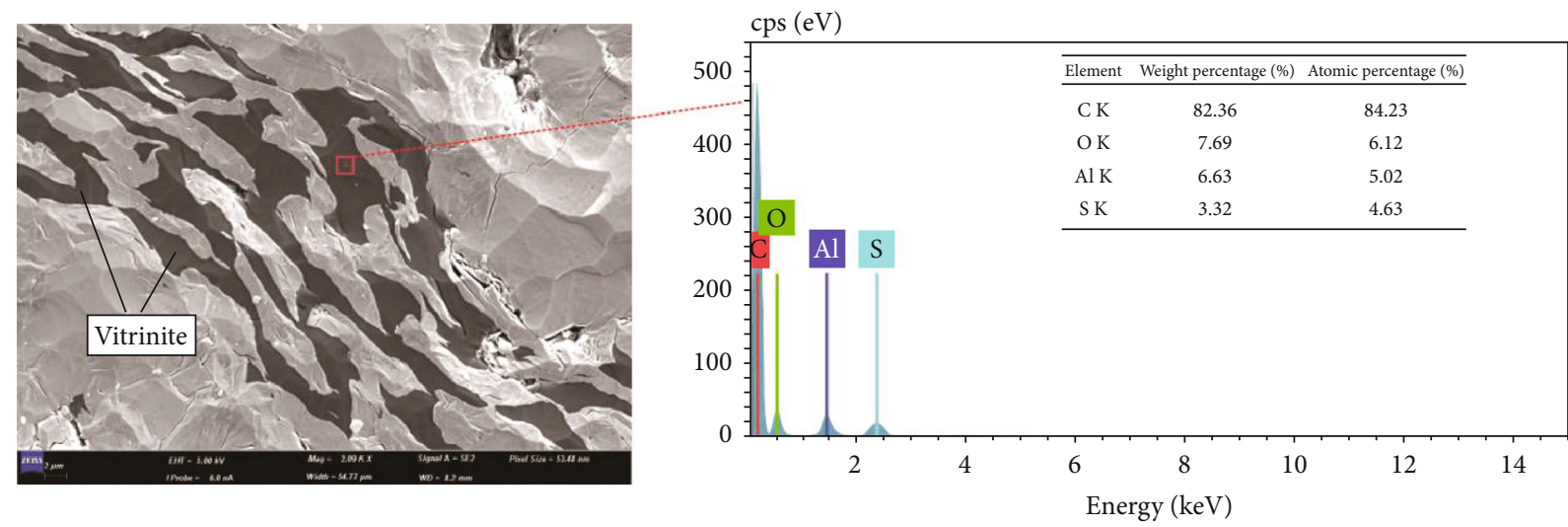

— Point

(c)

Figure 12: Continued. 

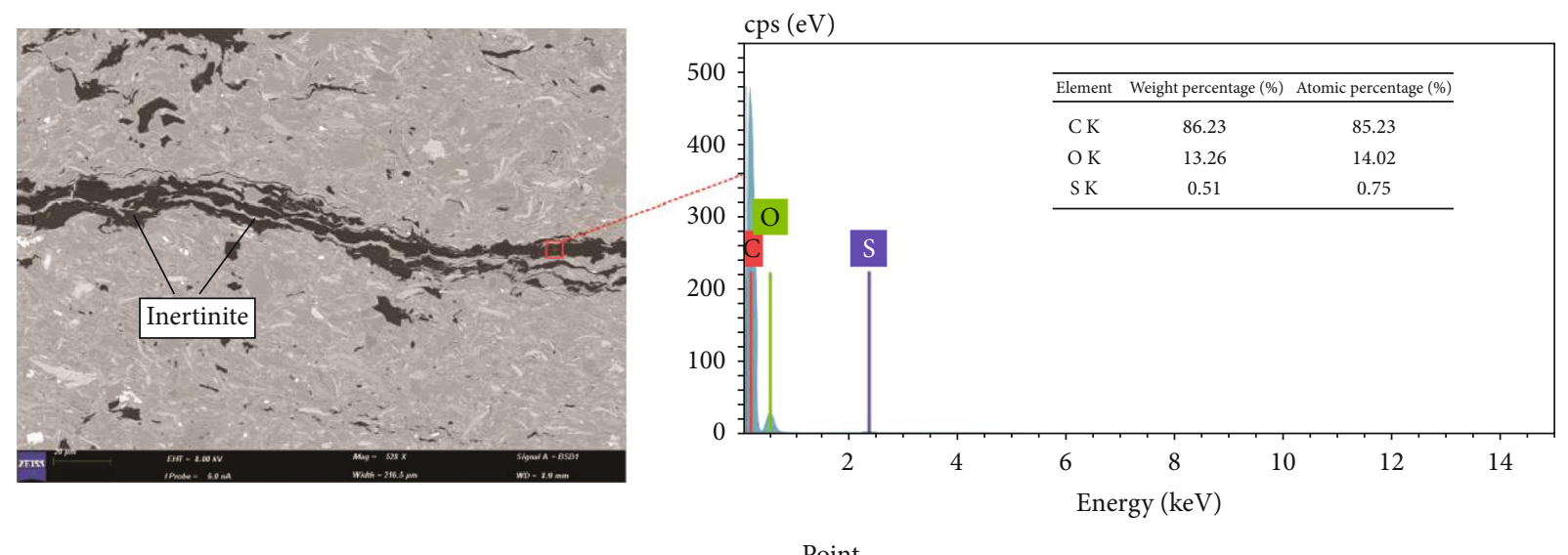

(d)

FIGURE 12: EDS of different macerals. (a) YY34, $1388.97 \mathrm{~m}$, sapropelite. (b) YY8, $1451.04 \mathrm{~m}$, exinite. (c) YY12, 1624.29 m, vitrinite. (d) YY13, $1206.44 \mathrm{~m}$, inertinite. The EDS of the corresponding points are shown on the right.

The organic matter porosity of the Chang 7 shale samples was calculated to be between $0.44 \%$ and $1.06 \%$, and the contribution to the total porosity was about $11 \%$ to $47 \%$, accounting for an average of $26 \%$. Limited by the accuracy of the software, pores smaller than $5 \mathrm{~nm}$ were not included, so the actual organic matter porosity should be greater. As mentioned above, observations under FE-SEM found that there were great differences in the degree of organic matter pore development of different macerals. The hydrogen-rich macerals sapropelite and exinite developed large organic matter pores, while the organic matter pores of hydrogenpoor macerals vitrinite and inertinite were relatively underdeveloped, and the content of each maceral was different, which contributed to the different degrees of organic matter porosity. Therefore, in order to quantitatively evaluate the contribution of each maceral to the organic matter porosity, the contribution of each maceral was calculated by using the mass percentage and the average Phi (a certain maceral contribution $=$ mass percentage $\times$ average $\mathrm{Phi}$ ). It can be seen from Table 2 that the sapropelite provided the most organic matter pores, with a contribution percentage of $94.96 \%$, while the inertinite provided almost no organic matter pores, with the lowest contribution of $0.06 \%$.

\subsection{Relationship between Macerals and Potential} Hydrocarbon Generation. Different macerals have different capacities of hydrocarbon generation. Generally speaking, the higher the content of hydrogen-rich sapropelite and exinite, the better the capacity of hydrocarbon generation. The relative content of hydrogen-rich macerals was positively correlated with TOC and $S_{1}+S_{2}$ (Figures 11(a) and 11(b)), which indicated that the hydrogen-rich macerals are the favorable hydrocarbon-generating macerals of Chang 7 shale. There was no obvious correlation between hydrogenpoor macerals and TOC and $S_{1}+S_{2}$ (Figures 11(c) and $11(d))$, indicating that the capacity for hydrocarbon generation is weak and that inertinite is the maceral with the lowest capacity for hydrocarbon generation. The relative content of hydrogen-poor macerals in the Chang 7 shale was relatively low and had little influence on the capacity for hydrocarbon generation of the shale.

The carbon and hydrogen contents of organic matter are usually used to judge the hydrocarbon generation potential. The higher the weight percentage of carbon and the lower the weight percentage of hydrogen, the lower the hydrocarbon generation potential. As the EDS can only measure the weight percentage of carbon, the measured carbon level was used to judge the difference in hydrocarbon generation potential of each maceral. Using the EDS of each maceral of some samples as examples, the weight percentage of carbon in the sapropelite was $40 \% \sim 60 \%$ (Figure 12(a)); the weight percentage of carbon in the exinite was $60 \% \sim 70 \%$ (Figure 12(b)); the weight percentage of carbon measured in the vitrinite was $80 \% \sim 90 \%$ (Figure $12(\mathrm{c})$ ); the weight percentages of carbon in inertinite and vitrinite were similar, ranging from $85 \%$ to $90 \%$ (Figure $12(\mathrm{~d})$ ). It can be seen from sapropelite, exinite, vitrinite, and inertinite that the weight percentage of carbon increases successively, indicating that the hydrocarbon generation potential is successively worsened. This is consistent with the previous research results $[6,28]$.

5.3. Control of Gas Content by Macerals. Macerals are an important factor affecting the capacity of hydrocarbon generation of organic matter, and they also control the gas content of shale reservoirs. At present, there are few studies on the effect of maceral content on shale adsorption capacity. The adsorption gas content measured by the methane isotherm adsorption experiment was a comprehensive reflection of gas adsorption on the surface of organic matter and inorganic minerals. In order to accurately analyze the adsorption volume of organic matter, assuming that methane molecules are uniformly adsorbed on the surface of organic and inorganic matter pores, the adsorption volume of organic matter was calculated according to the proportion of organic matter pores out of the total pores.

According to the statistical analysis of the relationship between the macerals of Chang 7 shale in the Yanchang 


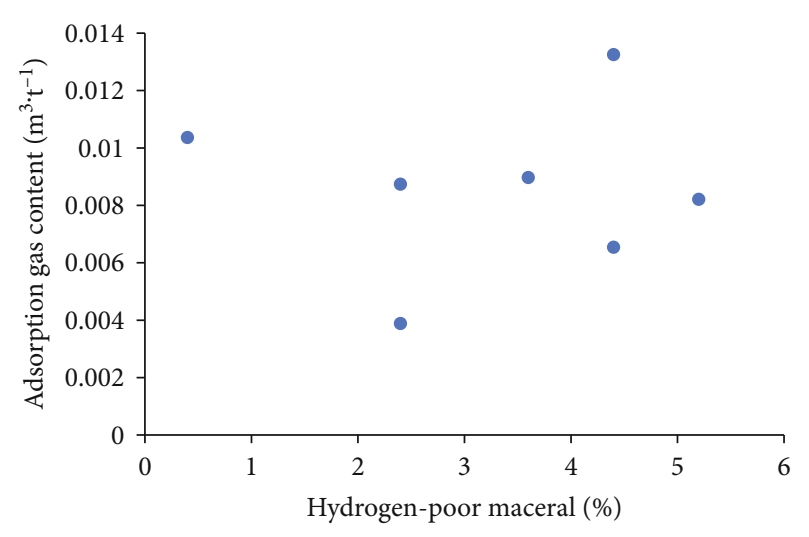

(a)

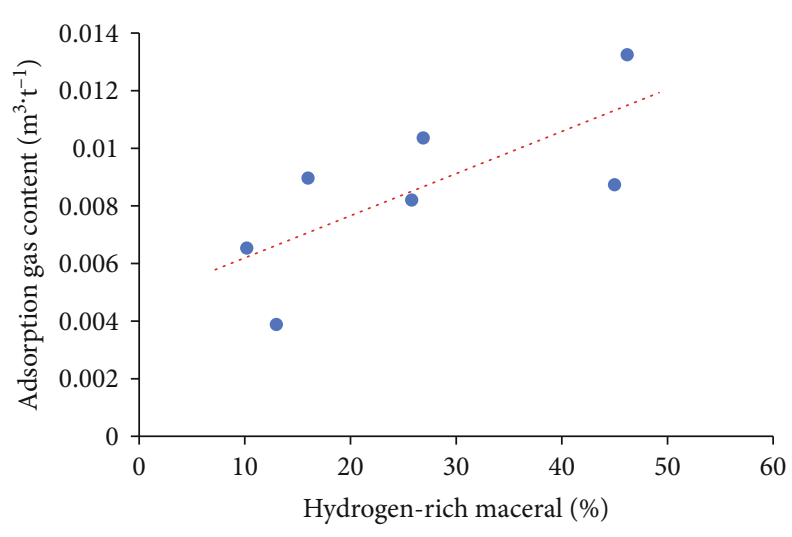

(b)

FIGURE 13: Relationships between macerals and adsorbed gas.

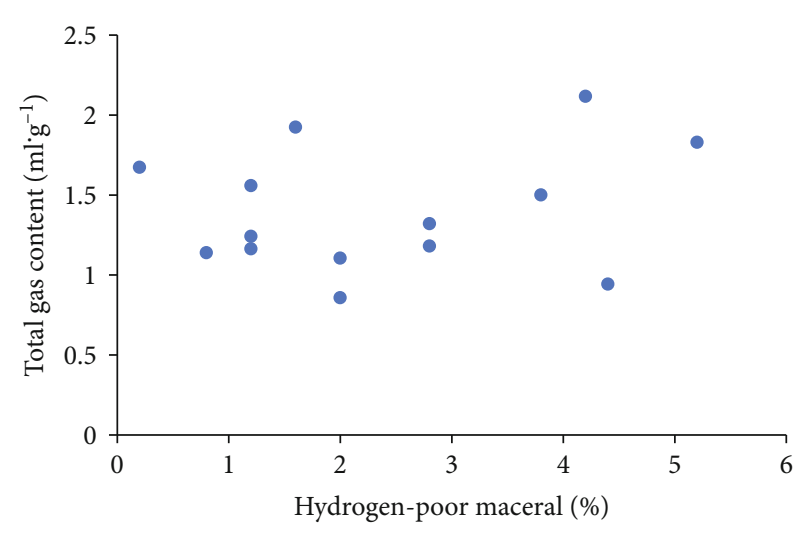

(a)

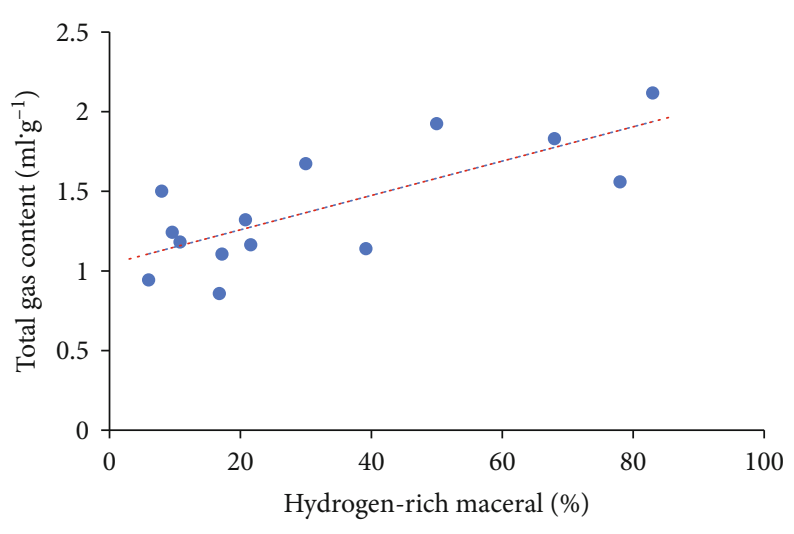

(b)

FIGURE 14: Relationships between macerals and total gas content.

Formation and the adsorption amount of organic matter, there was no significant correlation between the hydrogenpoor macerals and the adsorption amount of organic matter (Figure 13(a)). There was also a positive correlation between the hydrogen-rich macerals and the adsorption amount of organic matter (Figure 13(b)). A large number of organic matter pores are developed in hydrogen-rich macerals, which provide more surface area and more adsorption sites for gas, so the adsorption capacity is increased. However, the organic matter pores of hydrogen-poor macerals are not developed, so they are not conducive to gas adsorption.

Shale gas is the product of kerogen evolution and mainly exists in shale pores in free and adsorbed states. According to the statistical analysis of the relationship between macerals and total gas content in Chang 7 shale of the Yanchang Formation, there was no obvious correlation between hydrogenpoor macerals and total gas content (Figure 14(a)). The hydrogen-rich macerals were positively correlated with the total gas content (Figure 14(b)). Hydrogen-rich macerals have a good capacity for hydrocarbon generation, which can generate a lot of shale gas and develop more organic matter pores, providing space for the occurrence of shale gas. However, the hydrogen-poor macerals have a worse capacity for hydrocarbon generation, the organic matter pores are not developed, and the content of hydrogen-poor macerals in
Chang 7 shale was low, so it had no obvious contribution to the total gas content.

\section{Conclusion}

Based on our studies, the following conclusions can be drawn:

(1) FE-SEM and EDS can effectively identify the various macerals. Based on the morphology and elements of the organic matter of the Chang 7 member, the synthetic discrimination method of organic macerals was established. Sapropelite was mainly composed of the mineral asphalt matrix, followed by algae; exinite was composed of sporophyte and resin; vitrinite had a small amount of provitrinite, euvitrinite, and vitrodetrinite; inertinite was composed of semifusinite and inertodetrinite

(2) The sapropelite developed a large number of honeycomb pores, and the exinite developed roundelliptical stomata; a small amount of organic matter pores and microfractures were seen in vitrinite and inertinite. Further calculations showed that the sapropelite provides the most organic matter pores, 
with a contribution percentage of $94.96 \%$, and the inertinite provides almost no organic matter pores, with a contribution percentage of $0.06 \%$

(3) The EDS showed that the weight percentage of carbon increases successively in the order of sapropelite, exinite, vitrinite, and inertinite, which indicates that the hydrogen-rich macerals have a better hydrocarbon generation capacity, and the hydrogen-poor macerals have a lower hydrocarbon generation capacity. The hydrogen-rich macerals have a positive correlation with the organic matter adsorption gas volume and total gas content, while the hydrogenpoor macerals have no obvious correlation. Sapropelite and exinite are conducive to the generation of shale gas and develop rich organic matter pores. They can provide space for shale gas reservoirs. Vitrinite and inertinite do not develop organic matter pores and are not conducive to the generation and storage of hydrocarbons

\section{Data Availability}

The data used to support the study is available within the article.

\section{Conflicts of Interest}

The authors declare that they have no conflicts of interest.

\section{Acknowledgments}

This research was supported by the National Science and Technology Major Project of China (No. 2016ZX05034001) and the National Natural Science Foundation of China (No. 41502123).

\section{References}

[1] Z. Chen, G. Liu, Z. Cao et al., "Origin of solid bitumen and its significance to petroleum geology: a case study of Baikouquan formation in Mahu sag of Junggar basin," Journal of China University of Mining \& Technology, vol. 47, no. 2, pp. 391399, 2018.

[2] G. J. Nowak, "Comparative studies of organic matter petrography of the late palaeozoic black shales from Southwestern Poland," International Journal of Coal Geology, vol. 71, no. 4, pp. 568-585, 2007.

[3] D. Kondla, H. Sanei, C. R. Clarkson, O. H. Ardakani, X. Wang, and C. Jiang, "Effects of organic and mineral matter on reservoir quality in a Middle Triassic mudstone in the Canadian Arctic," International Journal of Coal Geology, vol. 153, pp. 112-126, 2016.

[4] J. Kus, "Application of confocal laser-scanning microscopy (CLSM) to autofluorescent organic and mineral matter in peat, coals and siliciclastic sedimentary rocks - a qualitative approach," International Journal of Coal Geology, vol. 137, pp. 1-18, 2015.

[5] A. Ghosh, "AuroView 2000-an optical image processing system in rank and grade analysis of coal," Journal of the Geological Society of India, vol. 60, no. 2, pp. 143-150, 2002.
[6] G. Fenglin, S. Yan, L. Zhikai, L. Zhuo, Y. Yuan, and Z. Yinghan, "Development characteristics of organic pore in the continental shale and its genetic mechanism: a case study of Shahezi Formation shale in the Changling fault depression of Songliao Basin," Acta Petrolei Sinica, vol. 40, no. 9, pp. 1030-1044, 2019.

[7] H. J. Guo, R. L. He, W. L. Jia et al., "Pore characteristics of lacustrine shale within the oil window in the Upper Triassic Yanchang Formation, southeastern Ordos Basin, China," Marine and Petroleum Geology, vol. 91, pp. 279-296, 2018.

[8] W. M. Ji, Y. Song, Z. H. Rui, M. Meng, and H. Huang, "Pore characterization of isolated organic matter from high matured gas shale reservoir," International Journal of Coal Geology, vol. 174, pp. 31-40, 2017.

[9] X. Z. Song, "Effect of false boundary of microscopic image on automatic identification of maceral group," Coal Geology \& Exploration, vol. 47, pp. 45-50, 2019.

[10] Q. Li, S. H. Wu, D. L. Xia, X. You, H. Zhang, and H. Lu, “Major and trace element geochemistry of the lacustrine organic-rich shales from the Upper Triassic Chang 7 Member in the southwestern Ordos Basin, China: implications for paleoenvironment and organic matter accumulation," Marine and Petroleum Geology, vol. 111, pp. 852-867, 2020.

[11] C. He, L. M. Ji, A. Su et al., "Source-rock evaluation and depositional environment of black shales in the Triassic Yanchang Formation, southern Ordos Basin, north-central China," Journal of Petroleum Science and Engineering, vol. 173, pp. 899911, 2019.

[12] X. Tang, J. C. Zhang, X. Z. Wang et al., "Shale characteristics in the southeastern Ordos Basin, China: implications for hydrocarbon accumulation conditions and the potential of continental shales," International Journal of Coal Geology, vol. 128-129, pp. 32-46, 2014.

[13] X. Z. Wang, S. L. Gao, and C. Gao, "Geological features of Mesozoic lacustrine shale gas in south of Ordos Basin, NW China," Petroleum Exploration and Development, vol. 41, no. 3, pp. 326-337, 2014.

[14] H. Yang, X. Niu, L. Xu et al., "Exploration potential of shale oil in Chang7 Member, Upper Triassic Yanchang Formation, Ordos Basin, NW China," Petroleum Exploration and Development, vol. 43, no. 4, pp. 560-569, 2016.

[15] F. J. Jiang, D. Chen, Z. F. Wang et al., "Pore characteristic analysis of a lacustrine shale: a case study in the Ordos Basin, NW China," Marine and Petroleum Geology, vol. 73, pp. 554-571, 2016.

[16] J. Fu, S. Li, X. Niu, X. Deng, and X. Zhou, "Geological characteristics and exploration of shale oil in Chang 7 Member of Triassic Yanchang Formation, Ordos Basin, NW China," Petroleum Exploration and Development, vol. 47, no. 5, pp. 931-945, 2020.

[17] Y. Li, D. Tang, P. Wu et al., "Continuous unconventional natural gas accumulations of Carboniferous-Permian coalbearing strata in the Linxing area, northeastern Ordos basin, China," Journal of Natural Gas Science and Engineering, vol. 36, pp. 314-327, 2016.

[18] Y. B. Yao, D. Liu, D. Tang, S. Tang, and W. Huang, "Fractal characterization of adsorption-pores of coals from North China: an investigation on $\mathrm{CH}_{4}$ adsorption capacity of coals," International Journal of Coal Geology, vol. 73, no. 1, pp. 2742, 2008.

[19] A. C. Cook and N. R. Sherwood, "Classification of oil shales, coals and other organic-rich rocks," Organic Geochemistry, vol. 17 , no. 2, pp. 211-222, 1991. 
[20] M. Ercegovac and A. Kostic, "Organic facies and palynofacies: nomenclature, classification and applicability for petroleum source rock evaluation," International Journal of Coal Geology, vol. 68, no. 1-2, pp. 70-78, 2006.

[21] K. M. Cheng, T. G. Wang, and S. Q. Zhao, "Geochemistry and evolution characteristics of source rocks," Research Institute of Petroleum Exploration and Development, Beijing, 1989.

[22] H. Zhang, S. J. Jiao, and G. H. Li, "Scanning electron microscopy study of unconventional oil and gas reservoirs," Geological Publishing House, Beijing, 2016.

[23] Y. F. Jiang, L. Zhao, G. Q. Zhou et al., "Petrological, mineralogical, and geochemical compositions of Early Jurassic coals in the Yining Coalfield, Xinjiang, China," International Journal of Coal Geology, vol. 152, pp. 47-67, 2015.

[24] W. M. Ji, F. Hao, H. M. Schulz, Y. Song, and J. Tian, “The architecture of organic matter and its pores in highly mature gas shales of the lower Silurian Longmaxi Formation in the upper Yangtze platform, south China," AAPG Bulletin, vol. 103, no. 12, pp. 2909-2942, 2019.

[25] E. Tannenbaum and I. R. Kaplan, "Role of minerals in the thermal alteration of organic matter-I. Generation of gases and condensates under dry condition," Geochimica et Cosmochimica Acta, vol. 49, no. 12, pp. 2589-2604, 1985.

[26] M. Shi, B. Yu, Z. Xue, J. Wu, and Y. Yuan, "Pore characteristics of organic-rich shales with high thermal maturity: a case study of the Longmaxi gas shale reservoirs from well Yuye-1 in southeastern Chongqing, China," Journal of Natural Gas Science and Engineering, vol. 26, pp. 948-959, 2015.

[27] C. Yang, J. Zhang, X. Tang et al., "Comparative study on micro-pore structure of marine, terrestrial, and transitional shales in key areas, China," International Journal of Coal Geology, vol. 171, pp. 76-92, 2017.

[28] H. Zhang, S. Jiao, Q. Pang, N. Li, and B. Lin, "SEM observation of organic matters in the Eopaleozoic shale in South China," Oil \& Gas Geology, vol. 36, no. 4, pp. 675-680, 2015. 